\title{
VAulted Into Victims: Preventing FURTHER SEXUAL ABUSE IN U.S. OLYMPIC SPORTS THROUGH UNIONIZATION AND IMPROVED GOVERNANCE
}

\author{
Marc Edelman* \& Jennifer M. Pacella**
}

For almost two decades, a sexual predator groomed and abused hundreds of young, female athletes. All the while, he held an esteemed position as the national team doctor for USA Gymnastics, the national governing body for the sport of U.S. gymnastics, and served on the faculty at Michigan State University, where he treated countless female athletes in his sports medicine clinic. This predator, Larry Nassar, is now behind bars for life. At his sentencing hearings in 2018, hundreds of his victims, many of whom were Olympians, courageously came forward detailing their accounts of sexual abuse at the hands of Nassar, who veiled his abuse and molestation as "legitimate medical treatments" for injured athletes. Many of Nassar's long list of victims were just children when he abused them (some as young as age ten), and, thus they were unable to comprehend what was happening to them as they pursued their dreams. The nation is now left baffled as to how this abuse persisted for so long and why USA Gymnastics failed to properly detect and stop it. This Article, which is the first scholarly piece to address the USA Gymnastics tragedy from a legal and regulatory perspective, aims to answer the above questions by analyzing the cultural and structural failures within USA Gymnastics that led to this abuse, and by proposing two major governance reforms within the world of U.S. Olympic sports to greatly decrease the likelihood that such a tragedy would ever

* Professor Marc Edelman (Marc@MarcEdelman.com) is a tenured Professor of Law at the Zicklin School of Business, Baruch College, City University of New York. He is also an adjunct professor at Fordham University School of Law and a columnist for Forbes SportsMoney. Professor Edelman advises numerous businesses on legal issues related to antitrust, gaming, intellectual property, and sports law.

** Professor Jennifer M. Pacella is an Assistant Professor of Business Law and Ethics at the Kelley School of Business, Indiana University. Professor Pacella is a subject matter expert on whistleblowing law and compliance, and presents nationwide on the status of legal protections for whistleblowers.

The Authors wish to thank Jason Petropoulos for providing research assistance for this Article. 
occur again. These reforms consist of the adoption of a robust whistleblower reporting system with appropriate antiretaliation protections and the unionization of gymnasts competing within USA Gymnastics so that the interests of vulnerable, young adults are adequately protected from a legal standpoint. The implementation of these legal and structural reforms will help to ensure that, going forward, the physical and emotional well-being of minor athletes is at the forefront of any organization that purports to protect them.

\section{TABLE OF CONTENTS}

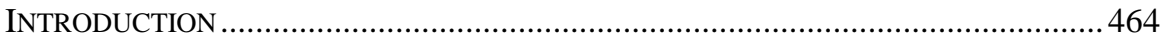

I. AN OVERVIEW OF THE U.S. WOMEN'S GYMNASTICS TRAGEDY .........................466

A. A Brief History of U.S. Gymnastics and USAG Organizational Structure 466

B. Larry Nassar's Sexual Abuse of More Than 250 U.S. Women's Gymnasts

II. How NASSAR's SEXUAL ABUSE OF U.S. WOMEN'S GyMnASTS REMAINED

UNDETECTED AND UNSTOPPED....................................474

A. Internal Power Inequities and Unbearable Demands for Perfection ........... 474

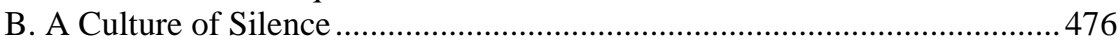

C. Lack of Adequate Internal and External Reporting Channels ..................... 479

III. Legal AND StRUCtURAL Reform to PREVENT ANOther SEXUAl Abuse



A. Whistleblower Protection Systems …………...........................................483

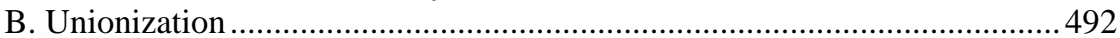

1. Unionizing Goals and Legal Standards ..............................................493

2. Elite U.S. Women's Gymnasts as Employees ...........................................496

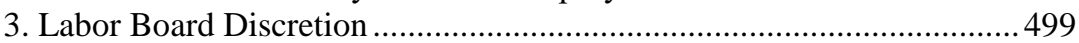

CONCLUSION 501

\section{INTRODUCTION}

On February 5, 2018, Larry Nassar, the former USA Gymnastics and Michigan State University sports medicine doctor, was sentenced to 40 to 125 years of imprisonment for his sexual abuse of hundreds of young female athletes over the course of nearly 20 years. ${ }^{1}$ Nassar sexually molested and abused more than 250 young women during his years working as their physician. ${ }^{2}$ Most of those abused

1. Christine Hauser, Larry Nassar Is Sentenced to Another 40 to 125 Years in Prison, N.Y. TimES (Feb. 5, 2018), https://www.nytimes.com/2018/02/05/sports/larry-nassarsentencing-hearing.html; see also LANSING STATE J. \& INDYSTAR, Who is Larry Nassar?, INDYSTAR, https://www.indystar.com/pages/interactives/larry-nassar-timeline/ (last visited July 11, 2019).

2. See Alanna Vagianos, 140 Women Have Accused Larry Nassar Of Abuse. His Victims Think We Don't Care, Huffington Post (Jan. 14, 2018), https://www.huffingtonpost.com/entry/larry-nassar-abuse-victims-public-

outrage_us_5a58f619e4b03c4189654efe (estimating the number of young women abused by Dr. Nassar at upwards of 140 in 2018); Ed White \& David Eggert, New Larry Nassar Victims 
were young girls or teenagers at the time, many of whom courageously gave powerful victim impact statements at Nassar's sentencing hearings in 2018. ${ }^{3}$ During these statements, his victims detailed the intensive physical and emotional abuse that they suffered at the hands of Nassar during their many years of athletic training and the lingering negative effects of this abuse on their self-esteem and personal confidence. $^{4}$

While one of the judges in Nassar's case described the sexual trauma Nassar inflicted on the numerous young gymnasts as "incomprehensible," it is critical to recognize that this tragedy was due to more than just Nassar's disturbed mental state. It was also facilitated by the failed governance of Nassar's former employer, USA Gymnastics ("USAG"), the national governing body for the sport of U.S. gymnastics, which for years, failed to both detect and respond to the abuse. ${ }^{6}$ While social psychologists are best poised to analyze how a person like Nassar could engage in such monstrous behavior, our goal in this Article is to propose specific legal and structural reforms within the world of national organized sports to ensure that no sexual predator could ever again infiltrate a sport in which so many children and young athletes participate.

This Article argues that to adequately protect young athletes from another sexual abuse tragedy similar to the one that recently occurred within USAG, it is critical for the official national governing bodies for amateur sports to implement robust whistleblower protection systems and that the athletes themselves have a reasonable opportunity to organize and form a union to collectively bargain over their terms and conditions of employment. This Article will proceed in three parts. Part I provides an overview of the U.S. women's gymnastics tragedy, analyzing both the history of women's gymnastics in the United States and the sustained pattern of Nassar's sexual abuse that occurred in recent years under the purported supervision of USAG. Part II explores the underlying situational elements of USAG that allowed Nassar's sexual abuse of young female gymnasts to remain undetected for nearly two decades. This section will analyze the inequities in power dynamics within USAG, as well as the organization's culture of silence and lack of adequate internal and external reporting mechanisms. Finally, Part III calls for two important legal and structural reforms to prevent a similar tragedy to the one that occurred within USAG from occurring again in the future. These reforms consist of, first, the implementation of an effective whistleblower protection system with clear reporting

Are Expected to Speak as Number of Accusers Grows, YAHOо! (Jan. 31, 2018), https://www.yahoo.com/news/larry-nassar-victims-expected-speak-173820363.html.

3. Hauser, supra note 1.

4. See generally id. (discussing the reading of victim impact statements).

5. Id.

6. See ABOUT USA GyMNASTICS, https://usagym.org/pages/aboutus/pages/ about_usag.html (last visited June 8, 2019). In the aftermath of this tragedy, the United States Olympic Committee has sought to revoke USAG's status as a national governing body for the sport; see U.S. Olympic Comm., USOC Statement Regarding Action to Revoke USA Gymnastics' Recognition as Member National Governing Body, TEAmUSA (Nov. 5, 2018, 5:08 PM), https://www.teamusa.org/News/2018/November/05/USOC-Statement-RevokeUSA-Gymnastics-Recognition-As-Member-National-Governing-Body. 
mechanisms and retaliation protections, and second, the creation of a formal union body to represent and protect the interests of the young athletes who compete within each individual, amateur sport in this nation. It is the authors' hope that these reforms would ensure that the next generation of athletes has every opportunity to achieve personal and professional success, in addition to a healthy self-image, as they train to achieve their goals and dreams.

\section{AN OVERVIEW OF THE U.S. WOMEN'S GYMNASTICS TRAGEDY}

\section{A. A Brief History of U.S. Gymnastics and USAG Organizational Structure}

The sport of organized gymnastics emerged largely out of the "Turnverein" movement of 1800s Germany - a movement that was intended to enhance German physical fitness, military strength, and autonomy. ${ }^{7}$ As Turnvereins began to immigrate to the United States in search of greater freedoms, they brought with them their acrobatic competitions, which first became popular in East Coast cities such as Baltimore, Boston, and New York. ${ }^{8}$ The first recorded competitive gymnastics activities in the United States took place at Harvard University in the mid-1800s. ${ }^{9}$ Although the United States initially paid little attention to the sport of gymnastics, it sent its first gymnastics team to compete in the 1936 Summer Olympics. ${ }^{10}$ In time, American gymnasts emerged as among the finest in the world. ${ }^{11}$

The performance of U.S. athletes in competitive gymnastics began to improve after 1978, when Congress passed the Amateur Sports Act, which chartered the U.S. Olympic Committee as the exclusive body to oversee Olympic sports in the United States and established separate, national bodies to oversee each individual

7. See Robert Knight Barney, German Turners in America: Their Role in Nineteenth Century Exercise Expression and Physical Education Legislation, in AMERICAN SPORT AND PhysicAl EduCATION History (TO 1975): AN ANTHOlogy 116, 116-17 (Earle F. Zeigler ed., 1975) (describing the movement as a response to the German's early 1800s military defeat to Napoleon).

8. Id. at $117-18$.

9. See id. at 118 .

10. See Ryan M. Rodenberg \& Andrea N. Eagleman, Uneven Bars: Age Restrictions, Antitrust, and Amateurism in Women's Gymnastics, 40 U. BALT. L. ReV. 587, 589 (2011); see also Tamara Best, Jesse Owens: A Chilly Reception in Nazi Germany, Then Olympic Glory, N.Y. TIMES (Aug. 8, 2016), https://www.nytimes.com/interactive/ projects/cp/obituaries/archives/jesse-owens (explaining that, while facing racial epithets and claims of Aryan superiority, Owens proceeded to win gold medals in the long jump, the 100meter dash, the 200-meter dash and the $4 \times 100$ relay). 1936 was the same year that U.S. track and field star Jesse Owens won four gold medals while representing the country.

11. Cf. Ann Chisholm, Gymnastics, in 2 SPORTS IN AMERICA: From Colonial Times to the Twenty-First Century: An EnCyClopedia 433-34 (Steven A. Reiss ed., 2011) (noting that "American gymnastics did not perform to international standards in the decades following WW2" and that the sport was dominated by the Soviet Union and its Eastern European allies, a particular embarrassment for the United States during the Cold War). 
Olympic sport. ${ }^{12}$ In conjunction with the passing of the Amateur Sports Act, the U.S. Olympic Committee named USAG as the official national governing body for all U.S. gymnastics events - thus transforming USAG into a quasi-subsidiary of the U.S. Olympic Committee, as well as into the exclusive U.S. member of the Fédération Internationale de Gymnastique, the international governing body responsible for setting the rules related to global gymnastics competitions. ${ }^{13}$ Currently, USAG is structured as a 501(c)(3), not-for-profit organization, and governed by a 15 -member board of directors. ${ }^{14}$

Not long after USAG gained control over organized U.S. gymnastics, the U.S. women's gymnastics team experienced its first real Olympic success when, in the 1984 Olympics in Los Angeles, 16-year-old West Virginia native, Mary Lou Retton, became the first U.S. gymnast to win an all-around gold medal. ${ }^{15}$ By upsetting Romanian favorite Ecaterina Sazbo by 0.05 points at the all-around event, Mary Lou Retton catapulted both herself and her coach to legendary status. ${ }^{16}$ Retton's coach at the time was Bela Karolyi, a Romanian defector who had previously coached elite Soviet gymnasts. ${ }^{17}$ Based on his success at training Mary Lou Retton (among others), USAG thereafter named Bela Karolyi as the team's new head coach and gave Karolyi's wife, Marta, broad control over all logistical tasks related to U.S. women's gymnastics. ${ }^{18}$ The goal was to help produce more U.S. gymnasts on the level of Mary Lou Retton - a result they believed would allow the United States to compete more favorably against Russia in future Olympics, an especially important goal in light of the Cold War. ${ }^{19}$ Although USAG initially may have maintained some oversight over the Karolyi family, with each passing gymnastics victory over the Russians, the Karolyis gained more autonomy, and the U.S. women's gymnastics team went on to win five medals in the 1992 Olympic

12. See Juli Anne Patty, The Gymnastics World, SPORTs Destination Mgmt. (June 30, 2008), http://www.sportsdestinations.com/sports/gymnastics/the-gymnasticsworld-4490.

13. Id.; see also About USA Gymnastics, USA GYMNASTICS, https://usagym.org/ pages/aboutus/pages/about_usag.html (last visited July 18, 2019). But see Rodenberg \& Eagleman, supra note 10, at 589 (tracing the oversight role of USA Gymnastics back even further to 1970).

14. About USA Gymnastics, supra note 13; see also USA GYMNASTICS, BYLAWS 9 (May 22, 2018), https://usagym.org/PDFs/About\%20USA\%20Gymnastics/Governance/ usag-bylaws.pdf.

15. Rodenberg \& Eagleman, supra note 10, at 589-90.

16. Elliott Almon, Catching up with Mary Lou Retton, Olympic Darling of 1984, MerCuRY News (March 30, 2016, 10:12 AM), https://www.mercurynews.com/2016/ 03/30/catching-up-with-mary-lou-retton-olympic-darling-of-1984/; Dvora Meyers, How Bela and Martha Karolyi Made America Great, Slate (Aug. 5, 2016, 11:11 AM), https://slate.com/culture/2016/08/how-bela-and-martha-karolyi-transformed-u-s-womensgymnastics.html.

17. Rodenberg \& Eagleman, supra note 10, at 590.

18. Id.

19. See id. See generally Chisholm, supra note 11, at 433-34 (further explaining the embarrassment of the United States in its failure to compete effectively in gymnastics against Eastern Bloc nations during the Cold War). 
Games in Barcelona, Spain under the Karolyis' training. ${ }^{20}$ The team won four more in the 1996 games in Atlanta, Georgia, and one medal in the 2000 Olympics in Sydney, Australia. ${ }^{21}$

After more than a decade of overseeing USAG, Bela Karolyi stepped back from his role with the U.S. women's Olympics team after the United States took fourth place at the 2000 Olympics; at that time his wife, Marta, replaced him as the team's coach and she proceeded to take on an even broader presence in the sport. ${ }^{22}$ Under Marta's oversight, winning in U.S. gymnastics went from being very important to meaning absolutely everything-irrespective of any regard for the emotional and physical well-being of the athletes. ${ }^{23}$ Marta, upon becoming coach, began to require the nation's elite gymnasts to train several times a year in a program run out of her family's Texas ranch, "the Karolyi Ranch." 24 This unconventional and centralized training regime continued until January 18, 2018, when USAG finally ended its association with the Ranch in the aftermath of hundreds of U.S. women's gymnasts revealing the sexual abuse they suffered at the hands of Nassar, ${ }^{25}$ which often took place there. ${ }^{26}$

\section{B. Larry Nassar's Sexual Abuse of More Than 250 U.S. Women's Gymnasts}

Larry Nassar, the individual guilty of sexually abusing hundreds of innocent female gymnasts, had a long history of working in the medical field,

20. Rodenberg \& Eagleman, supra note 10, at 590.

21. Id. (referencing the 1996 success of the U.S. women's gymnastics team); 2000 Olympic Team Receives Bronze Medals at Visa Championships, USA GYMNASTICS (Aug. 11, 2011), https://usagym.org/pages/post.html?PostID=6001 (indicating that the 2000 U.S. women's gymnasts only were awarded bronze medals years later after the team from China was disqualified).

22. Rodenberg \& Eagleman, supra note 10, at 590; see, e.g., Juliet Macur, Final Bow for Martha Karolyi, the Woman Who Lifted U.S. Gymnastics, N.Y. TiMES (Aug. 9, 2016), https://www.nytimes.com/2016/08/10/sports/olympics/final-bow-for-martha-karolyi-thewoman-who-lifted-us-gymnastics.html.

23. See generally Rodenberg \& Eagleman, supra note 10 (explaining that the U.S. women's gymnastics team instituted new practices under Marta Karolyi including practicing away from home for extended periods of time).

24. Id. at 590 .

25. Eric Levenson, USA Gymnastics Cuts Ties with Karolyi Ranch and Its Memories of Abuse, CNN (Jan. 19, 2018, 3:43 AM), https://www.cnn.com/2018/01/18/ us/usa-gymnastics-karolyi-ranch/index.html ("USA Gymnastics has terminated its agreement with the Karolyi Ranch in Huntsville, Texas. It will no longer serve as the USA Gymnastics National Team Training Center." (quoting Kerry Perry, President and CEO of USA Gymnastics)).

26. See Dan Murphy \& John Barr, USA Gymnastics Cuts Ties with Karolyi Ranch Training Facility, ESPN (Jan. 19, 2018), http://www.espn.com/olympics/story/_id/ 22145103/usa-gymnastics-cuts-ties-karolyi-ranch-training-facility (explaining how Dr. Nassar even groomed the young women's gymnasts for sexual abuse at the ranch by giving them snacks and treats and other items that the Karolyi family forbid them from having). For the estimate of the total number of young women's gymnasts abused by Dr. Nassar of about 140, see Vagianos, supra note 2. 
specifically in gymnastics. ${ }^{27}$ As a teenager in 1978, Nassar began working with gymnasts as a student athletic trainer at North Farmington High School in the suburbs of Detroit. ${ }^{28} \mathrm{He}$ later graduated from the University of Michigan with a bachelor's degree in kinesiology in 1985 and then a medical degree from the College of Osteopathic Medicine at Michigan State University ("MSU") in 1993. ${ }^{29}$

Even before officially obtaining his medical degree, Nassar began working for USAG in 1986 as an athletic trainer and, in 1996, he became the team's national medical coordinator. ${ }^{30}$ After completing a primary care sports medicine fellowship in 1997, Nassar began his affiliation with MSU as medical faculty and assumed the role of team physician for several MSU sports teams until he was fired because of the sexual abuse allegations in $2016 .{ }^{31}$ From approximately 1998 to 2015 , USAG employed Nassar in various esteemed roles, including the titles of National Team Physician, National Medical Director, Certified Athletic Trainer, and Osteopathic Physician. $^{32}$

Almost immediately upon beginning his career, Nassar began to sexually abuse young women who were sent to him by their coaches within USAG or within the MSU network to receive his medical care. ${ }^{33}$ The truth about these long and tragic years of abuse finally came to light when two former gymnasts, one of whom is an Olympic medalist, came forward to the Indianapolis Star in September 2016 after individually filing civil and criminal complaints alleging that Nassar had sexually abused them beginning in the early 1990s. ${ }^{34}$ Shortly thereafter, numerous other women came forward alleging the same sexual abuse and, today, a total of 265 victims have come forward. ${ }^{35}$

Nassar's victims each experienced the same pattern of abuse. ${ }^{36}$ Nearly all victims were young, female gymnasts or other athletes, at least 18 of whom are

27. See Kim Kozlowski, How MSU Doc Became Suspect in Dozens of Rapes, THE DETRoIT News (Aug. 11, 2017, 12:35 PM), http://www.detroitnews.com/ story/news/local/michigan/2017/08/10/rise-fall-larry-nassar/104491508/.

28. Id. (Nasser once noted on his Facebook page that "[his] high school years set a strong foundation for the rest of [his] life.").

29. Id.

30. LANSING STATE J. \& INDYSTAR, supra note 1.

31. Id.; see also Complaint, Doe v. Mich. St. U., No. 1:17-cv-00029-GJQ-ESC, 2017 WL 4679022, II 55 (W.D. Mich. Aug. 24, 2017). This is the first civil action to be brought against Nassar, MSU, USAG, and others affiliated with these institutions by one of Nassar's victims. The victim was a minor, and so the complaint was brought by her father. The victim and her father remained anonymous.

32. Complaint, supra note 31, II 39.

33. Tim Evans, Mark Alesia \& Marisa Kwiatkowski, Former USA Gymnastics Doctor Accused of Abuse, InDYSTAR (Sept. 12, 2016, 3:46pm), https://www.indystar.com/ story/news/2016/09/12/former-usa-gymnastics-doctor-accused-abuse/89995734/.

34. Complaint, supra note 31, II 55; see also Evans et al., supra note 33 (one of the women filed a civil suit against Nassar in California alleging the abuse, while the other filed a criminal complaint with police in Michigan).

35. White \& Eggert, supra note 2.

36. See, e.g., Carla Correa \& Meghan Louttit, More Than 160 Women Say Larry Nassar Sexually Abused Them. Here Are His Accusers In Their Own Words., N.Y. TIMES 
Olympic medalists, who suffered from an injury, physical pain, or soreness from countless hours of training (often presenting as hip, back, and leg pain) and were routinely sent to Nassar for medical treatment. ${ }^{37}$ Coaches, having no reason to question Nassar's integrity at that time, told the young women that Nassar was a "miracle worker" and "a knight in shining armor" who could "fix anyone or anything" experiencing physical pain - in fact, these athletes were often told that they were "lucky" to be treated by such a renowned doctor. ${ }^{38}$ Revered by his community as a truly skilled physician, Nassar was "seen as a man who was the best at what he did, so good that USA Gymnastics wanted him at the Olympics-they wanted him to be the one person on earth who would be treating their top athletes." ${ }^{39}$

Tragically, however, Nassar sexually abused hundreds of young women by penetrating his patients intra-vaginally with ungloved hands, guising this abuse and other fondling as a "massage" and as legitimate "treatment" that would help to eliminate the type of physical pain from training that the athletes had suffered. ${ }^{40}$ Nassar exploited these women, who were often minor children, by relying on the fact that a form of "pelvic floor" therapy that utilizes manipulation of internal vaginal soft tissue does exist. ${ }^{41}$ However, such therapy is used for conditions such as consistent pelvic pain, bowel and bladder issues like incontinence, and painful sexual intercourse - none of which are descriptive of the type of physical afflictions affecting gymnasts and other athletes. ${ }^{42}$ Further, osteopathic physicians like Nassar do not usually perform pelvic treatments. They are most often referred to physical therapists specialized and certified in that type of treatment, who are both supervised

(Jan. 24, 2018), https://www.nytimes.com/interactive/2018/01/24/sports/larry-nassarvictims.html; Associated PrESs, 'We Have the Power Now': The Statements from the Women Who Confronted Larry Nassar, CHI. TRIB. (Jan. 24, 2018, 9:59 AM), http://www.chicagotribune.com/sports/international/ct-nassar-victim-statements-20180124story.html.

37. See Correa \& Louttit, supra note 36 (setting forth excerpts of the various victim statements given at Nassar's sentencing hearings by the numerous women that Nassar abused).

38. See, e.g., id.; Virginia Heffernan, Dr. Larry Nassar Was Not a Doctor, L.A. TiMES (Jan. 26, 2018, 11:30 AM), http://www.latimes.com/opinion/op-ed/la-oe-heffernanlarry-nassar-20180126-story.html (discussing how Nassar "and his enablers" allowed the abuse to continue for years without discovery); see also Hadley Freeman, How Was Larry Nassar Able to Abuse So Many Gymnasts For So Long?, The GuARDian (Jan. 26, 2018), https://www.theguardian.com/sport/2018/jan/26/larry-nassar-abuse-gymnasts-scandalculture (discussing how the culture of gymnastics made it possible for Nassar to "groom" his victims).

39. 20/20: Sister Survivors (ABC television broadcast Jan. 26, 2018), at 10:05, http://abc.go.com/shows/2020/episode-guide/2018-01/26-012618-sister-survivors.

40. $\quad$ Alice Park, Aly Raisman Opens Up About Sexual Abuse by USA Gymnastics Doctor Larry Nassar, Time (Nov. 13, 2017), http://time.com/5020885/aly-raisman-sexualabuse-usa-gymnastics-doctor-larry-nassar/.

41. Roni Caryn Rabin, Pelvic Massage Can Be Legitimate, but Not in Larry Nassar's Hands, N.Y. TIMES (Jan. 31, 2018), https://www.nytimes.com/2018/01/31/well/ live/pelvic-massage-can-be-legitimate-but-not-in-larry-nassars-hands.html.

42. Id. 
while performing the treatments and usually female. ${ }^{43}$ Often, there was no other adult present in the room during Nassar's treatments, but, shockingly, at times an unknowing parent was actually present; in such instances, Nassar purposely positioned himself and the patient in a way that it would be impossible for the parent to know what Nassar was doing. ${ }^{44}$

Many of the women had not initially realized that Nassar's behavior constituted sexual abuse because they were so young (some were as young as nine years old) and simply trusted his behavior as a legitimate treatment - for many, it was not until years later, when the allegations of abuse finally emerged, that they realized they too had been victims of sexual abuse. ${ }^{45}$ Rachael Denhollander, a former Olympic gymnast who was 15 years old when first abused by Nassar, was the first person to publicly come forward with allegations of sexual abuse against him by filing a criminal complaint with the MSU Police in 2016, 16 years after she became a victim. ${ }^{46}$ Recalling what went through her mind as Nassar performed the "treatments" on her, all the while being told by him that this was a legitimate way to treat her pain, Denhollander's words below are telling of how Nassar persevered for so long without discovery:

I was terrified ... I was ashamed. I was very embarrassed. And I was very confused, trying to reconcile what was happening with the person he was supposed to be. He's this famous doctor. He's trusted by my friends. He's trusted by these other gymnasts. How could he reach this position in the medical profession, how could he reach this kind of prominence and stature if this is who he is ${ }^{47}$

Following Denhollander's public revelations, other victims filed numerous related complaints and lawsuits, the first of which was filed anonymously in 2017 in federal court in Michigan by the father of an abused minor against Nassar, MSU, MSU Trustees, members of the MSU Administration and faculty, and USAG. ${ }^{48}$ This complaint alleged that "under the false pretense" of proper medical care, Nassar sexually abused a minor, relying on "his position of trust and confidence" to commit abuse that resulted in "shock, humiliation, emotional distress and related physical manifestations thereof, embarrassment, loss of self-esteem, disgrace, and loss of enjoyment of life" for the victim. ${ }^{49}$ Similar sentiments were echoed by the hundreds

43. Id.

44. See Evans et al., supra note 33 (quoting Rachael Denhollander, the first victim of Nassar to publicly come forward to speak out about the abuse she had suffered).

45. Protecting Young Victims from Sexual Abuse Act and Safe Sport Authorization Act of 2017: Hearing on S. 534 Before the S. Comm. on the Judiciary, 115th Cong. (2017), https://www.c-span.org/video/?426087-1/olympic-gymnasts-recount-experiences-sexualabuse [hereinafter Senate Hearing] (statements of victims Jamie Dantzscher and Jessica Howard).

46. Evans et al., supra note 33 .

47. Id. (quoting Rachael Denhollander).

48. Complaint, supra note 31, II 1.

49. Id. TII 43-52; the Complaint goes on to state that "[b]ecause of Nassar's reputation, the Plaintiff's minor and her parents had no reason to doubt Nassar, as MSU, and USAG represented him to be a reputable, ethical, and trustworthy doctor." Id. II 47. 
of females who bravely came forward to give victim statements during Nassar's sentencing hearings in January 2018. ${ }^{50}$ These victims each gave heartbreaking statements, revealing the deep emotional scars stemming from the abuse they suffered and from the confusion as to how the pursuit of their dream could lead to such tragic results. ${ }^{51}$ One victim, abused by Nassar at only ten years of age, later committed suicide. ${ }^{52}$ Some of those voices are echoed below:

'He was the doctor. I was the child. I had no idea what to think.' 53

'You preyed on me, on us. You saw a way to take advantage of your position - the almighty and trusted gymnastics doctor . . . .54

'I remember he took me into the training room, closed the door and closed the blinds. At the time I thought this was kind of weird but figured it must be OK. I trusted what he was doing at first, but then he started touching me in places I really didn't think he should.' 55

'Imagine how it feels to be an innocent teenager in a foreign country hearing a knock on the door and it's you [Nassar]. I don't want you to be there, but I don't have a choice. Treatments with you were mandatory, and you took advantage of that. ${ }^{56}$

'[I] became so brainwashed by Larry [Nassar] and everyone at USA Gymnastics. Both whom I thought were supposed to be on my side. Nobody was protecting us from being taken advantage of. Nobody was even concerned whether or not we were being sexually abused. I was not protected, and neither were my teammates. My parents

50. Tracy Connor, 'Army of Women' Fights Gymnastics Doctor Larry Nassar With Words, NBC News (Jan. 24, 2018, 12:28 PM), https://www.nbcnews.com/news/usnews/army-women-fights-gymnastics-doctor-larry-nassar-words-n840481 (summarizing the sentiments of the numerous women who gave victims' statements at Nassar's sentencing hearings); see Zach Schonbrun \& Christine Hauser, Larry Nassar, Sentenced in Sexual Abuse Case, Is Back in Court, N.Y. TIMES (Jan. 31, 2018), https://www.nytimes.com/ 2018/01/31/sports/larry-nassar-sentencing.html (discussing the various victims who came forward to give statements at Nassar's various sentencing hearings).

51. See Schonbrun \& Hauser, supra note 50.

52. Nick Butler, Mother Claims Abuse by Nassar Drove Daughter to Suicide, INSIDE THE GAMES (Jan. 17, 2018), https://www.insidethegames.biz/articles/1060247/motherclaims-abuse-by-nassar-drove-daughter-to-suicide (noting Chelsea Markham's death); Aliya Kahn, Larry Nassar's Abuse Victim: Chelsea Markham's Suicide, EARn THE NECKLACE (Jan. 17, 2018, 10:18 AM), https://www.earnthenecklace.com/larry-nassars-abuse-victim-chelseamarkhams-suicide/ (Chelsea's mother gave a brave victim's impact statement in Chelsea's absence during his sentencing hearings).

53. ASSOCIATED PRESS, supra note 36.

54. Id. (victim statement of Clasina Syrov).

55. Id. (victim statement of Maggie Nichols).

56. D'Arcy Maine, Hear Larry Nassar's Victims in Their Own (Powerful and Brave) Words, ESPN (Jan. 24, 2018), http://www.espn.com/espnw/voices/article/22145563/ hear-larry-nassar-victims-their-own-powerful-brave-words (victim statement of Aly Raisman). 
trusted USA Gymnastics and Larry Nassar to take care of me, and we were betrayed by both.' 57

In November 2017, Nassar pleaded guilty to seven counts of first-degree criminal sexual conduct in Ingham County Circuit Court in Lansing, Michigan. ${ }^{58}$ On January 24, 2018, Judge Rosemarie Aquilina, who presided over Nassar's sentencing hearings for these charges and allowed the nearly 160 victims and parents to be present in court to give victims statements, sentenced Nassar to a maximum of 175 years in prison with no probation or parole. ${ }^{59}$ At sentencing, Judge Aquilina told Nassar the now-famous words: "I just signed your death warrant," commenting that, despite her belief in the rehabilitation of criminals when possible, she believed that rehabilitation is not possible with Nassar as "[he doesn't] get it" and remains a danger. ${ }^{60}$ This state sentence follows Nassar's December 2017 federal sentence, where he had already received 60 years imprisonment on child pornography charges, to which he pleaded guilty in federal court in July $2017 .{ }^{61}$ Nassar was also charged in Eaton County, Michigan with sexually abusing young female gymnasts at Twistars, a training facility in Michigan, to which he pleaded guilty to three counts of criminal sexual conduct. ${ }^{62}$ The sentencing hearings for these charges brought in dozens of more victims to offer their statements and, on February 5, 2018, Nassar received an additional state sentence of 40 to 125 years for these charges, which will run subsequent to the federal sentence (if Nassar is still alive) and concurrently with the other state sentence. ${ }^{63}$ Judge Janice Cunningham, who presided over these hearings, expressed the same concerns as Judge Aquilina, stating that Nassar could not fathom the wrongness of his actions or the devastating impact it has had on so

57. Id. (victim statement of Jordyn Wieber).

58. Char Adams, Former USA Gymnastics Doctor Larry Nassar Pleads Guilty to Sexually Abusing Girls in Michigan, PeOPLE (Nov. 22, 2017, 10:28 AM), https://people.com/ sports/larry-nassar-pleads-guilty-sexual-abuse-gymnasts/ (Nassar's guilty plea resulted from assurances that he would not be further charged from dozens of other additional victims).

59. Judge to Nassar: I Just Signed Your Death Warrant (CNN broadcast Jan. 24, 2018), https://www.cnn.com/videos/us/2018/01/24/larry-nassar-sentencing-judge-rosemarie -aquilina-death-warrant.cnn.

60. Id.

61. Id.; Alanna Vagianos, Larry Nassar Sentenced To 60 Years In Prison For Possessing Child Pornography, Huffington Post (Dec. 7, 2017, 1:34 PM), https://www.huffingtonpost.com/entry/larry-nassar-gymnastics-child-pornography_us_ 5a29751ee4b0b185e53a0f98; Ralph Ellis, Larry Nassar Transferred to Federal Prison in Arizona, CNN (Feb. 10, 2018, 7:28 PM), https://www.cnn.com/2018/02/10/us/larry-nassartransferred-to-tucson-prison/index.html (Nassar pleaded guilty to receiving child pornography in 2004, being in possession of thousands of images of child pornography from 2003 to 2016 and, in 2016, to destroying and concealing evidence while under investigation).

62. Eric Levenson, Larry Nassar Apologizes, Gets 40 to 125 Years for Decades of Sexual Abuse, CNN (Feb. 5, 2018, 2:17 PM), https://www.cnn.com/2018/02/05/us/larrynassar-sentence-eaton/index.html.

63. Amy Held, Larry Nassar Sentenced To Up To 125 Years Additional Prison Time, NPR (Feb. 5, 2018, 11:27 AM), https://www.npr.org/sections/thetwo-way/2018/02/ 05/583325479/larry-nassar-sentenced-to-up-to-125-years-additional-prison-time. 
many women, young girls, and their families. ${ }^{64}$ Nassar began serving his sentence in a high-security federal prison in February 2018. ${ }^{65}$

\section{How Nassar's SeXual Abuse OF U.S. Women's Gymnasts REMAINED UNDETECTED AND UNSTOPPED}

While Nassar deserves a lion's share of the blame for his monstrous acts in abusing hundreds of gymnasts, he is not alone to blame. ${ }^{66}$ Nassar was the lone perpetrator of sexual abuse, but various other individuals affiliated with USAG played a role in creating a culture of silence and fear in which everyone involved missed the warning signs of wrongdoing. ${ }^{67}$ This culture is best exemplified by the following horrifying quote from Bela Karolyi himself: "The young ones are the greatest little suckers in the world. They will follow you no matter what." ${ }^{28}$ This section will look at various aspects of the culture surrounding USAG that enabled Nassar to continue perpetrating his sexual abuse on young athletes for such a long period of time.

\section{A. Internal Power Inequities and Unbearable Demands for Perfection}

The first aspect of the culture underlying USAG that enabled Nassar to commit sexual abuse on young, female athletes for so long involves the internal power inequities and unbearable demands for perfection placed on the gymnasts by parents and coaches within USAG. ${ }^{69}$ Beginning with the appointment of the Karolyi family to their positions of control over the sport, USAG has operated under a culture where it is common for the young gymnasts to "be belittled by their coaches." 70 The norm has been for coaches to call the gymnasts insulting names like "butterball," "pregnant spider," or "tank" after a poor performance. ${ }^{71}$ To avoid risking the wrath of coaches and administrators, and knowing what defiance would

64. Levenson, supra note 62.

65. Ellis, supra note 61.

66. See generally Eryn M. Doherty, Winning Isn't Everything ... It's The Only Thing: A Critique of Teenaged Girls' Participation in Sports, 10 MARQ. SPORTS L.J. 127, 152 (1999) (suggesting that the formal sports regulating bodies have the moral, and perhaps legal, duty to protect the athletes and keep them physically and emotionally safe).

67. See Ludy T. Benjamin Jr. \& Jeffry A. Simpson, The Power of the Situation: The Impact of Milgram's Obedience Studies on Personality and Social Psychology, 64 AM. PSYCHOLOGIST 12, 15-17 (2009), https://pdfs.semanticscholar.org/1e36/ 4e27a2c49789990f5b4d150772e4323e4a6f.pdf (explaining how Stanley Milgram's psychological studies provide a "powerful demonstration that 'strong' situations can and sometimes do overwhelm personality variables even in well-intentioned and caring people"); see also ThOMAs Gilovich ET AL., SOCIAL Psychology 9-11 (4th ed. 2016) (discussing the strong situation created by Stanley Milgram's famous experiment and how participants "could not have guessed at the outset what the experiment involved, so they were not prepared to resist anyone's demands").

68. Doherty, supra note 66, at 136-37.

69. See infra notes 70-80 and accompanying text.

70. Kristin A. Hoffman, Comment, Flipping and Spinning into Labor Regulations: Analyzing the Need and Mechanisms for Protecting Elite Child Gymnasts and Figure Skaters, 25 MARQ. SPORTS L. REV. 565, 568 (2015).

71. Id. at 572 . 
cost them, many of the U.S. gymnasts transformed over time from confident young girls into "small, mute creatures who look at their coach as an idol and perform everything without ever talking back." ${ }^{72}$ In addition to the loss of self-esteem that resulted from ongoing social belittlement, USAG under the Karolyi family also exercised authoritarian power over the daily lives of the elite gymnasts. ${ }^{73}$ The U.S. women's gymnastics training program was all-encompassing, with the girls instructed to train at the Karolyi Ranch for "forty-six hours a week" and provided with rest breaks merely the following times: "only Sundays off, three days around Christmas, and one around the Fourth of July." ${ }^{74}$

Parents were not allowed to be present at the Karolyi Ranch with their daughters, and once there, the young gymnasts also surrendered all control of their own nutrition and calorie intake. ${ }^{75}$ It is well-documented that the Karolyi family limited gymnasts' calories while staying at the Ranch —often forcing them to go to bed hungry. ${ }^{76}$ While some of the girls initially protested and sought help from the male gymnasts in seeking food, many others ultimately developed and suffered from eating disorders. ${ }^{77}$ In addition, the coach-ordered limits on the calorie intake of the gymnasts led to other physical health problems like the delayed onset of menstruation. ${ }^{78}$

While some may expect that the gymnasts would have alerted their parents to these harsh training conditions, doing so would have probably yielded little benefit. Troublingly, some of the elite gymnasts' parents were likely aware of the strict conditions at the Karolyi Ranch, but they "abdicated many of their responsibilities to their child's coach" based on the Karolyi's track record of making young American girls into gymnastics stars. ${ }^{79}$ Even the families that may have expressed some concern with the Karolyi's methods seemed reluctant to pull their daughters from the program after they had already devoted hundreds of thousands

72. Id. at 569 (further explaining that Elena Moukina became paralyzed after attempting a dangerous tumbling trick for which she felt unprepared but also unable to escape doing); see also Doherty, supra note 66, at 136-37 (quoting Bela Karolyi about the level of control the Karolyi family sought to exercise over the young, women's gymnasts).

73. See Doherty, supra note 66, at 135 (describing the "authoritarian" control exercised over young women's gymnasts).

74. Hoffman, supra note 70, at 572.

75. See id. at 571-72.

76. See id.

77. Id. at 570-72; see also Jennifer Paul, Age Minimums in the Sport of Women's Artistic Gymnastics, 7 WiLlameTte SpORTS L.J. 73, 78 (2010) (explaining that Dominique Moceanu was pushed to compete for the 1996 U.S. Olympic team despite having a stress fracture in her tibia). See generally Stephanie L. Hamilton, The Feasibility of a Negligence Cause of Action for Gymnasts with Severe Eating Disorders, 2 U.C. DAvis J. JUV. L. \& POL'Y 44 (1997) (discussing the high prevalence of eating disorders in U.S. women's gymnastics).

78. See Hoffman, supra note 70, at 569-70 (noting that a study of women's gymnasts conducted by Oregon State University found that, perhaps due to their excessive exercise and required low weight, "college gymnasts begin menstruating at sixteen, while girls in general begin menstruating at thirteen.").

79. Doherty, supra note 66, at 135. 
of dollars to their training. ${ }^{80}$ Indeed, many of the parents lived vicariously through their daughters' gymnastics accomplishments, even though it was the girls who did all of the work and made the greatest nonfinancial sacrifices. ${ }^{81}$

\section{B. A Culture of Silence}

Given the troubling culture already endemic within USAG, it is perhaps not surprising that a sexual predator like Nassar was able to avoid public detection for so long despite committing abuse across the globe: including in his office, at various meets and athletic events, and even in the hotel rooms of the athletes at the Olympic Games. ${ }^{82}$ While not all of Nassar's victims were Olympic gymnasts, ${ }^{83}$ the culture of gymnastics was especially conducive to allowing Nassar to prey upon and manipulate young girls ${ }^{84}$ His abuse occurred frequently at the Karolyi Ranch-the single place where, as discussed, the young female gymnasts lived under the absolute greatest authoritarianism. ${ }^{85}$ As many with first-hand knowledge have revealed, it was the norm for gymnastics coaches and trainers both inside and outside of the Karolyi Ranch to be extremely strict, tough, intimidating, and even insulting to the gymnasts as they trained, pushing them to excellence no matter what the cost. It was against this backdrop that Nassar, as their doctor, groomed the young women, presenting himself as "the nice guy," often offering the athletes gifts, food, candy,

80. See id. at 132 (using $\$ 80,000$ as an example of the sum of money invested in a young athletes' training and used to create pressure to continue working toward a sport that long since had ceased being enjoyable); see also id. at 135 (projecting the amount of money that U.S. gymnast Dominique Moceanu's parents purportedly invested in her training as being in the ballpark of " $\$ 200,000 ")$.

81. See Paul, supra note 77 , at 79.

82. Senate Hearing, supra note 45 (statements of victims Jamie Dantzscher and Jessica Howard); see also Freeman, supra note 38 (discussing how the culture of gymnastics made it possible for Nassar to "groom" his victims).

83. See Lauren Hopkins, Larry Nassar Was a Master Manipulator, but He Didn't Act Alone, Huffington Post (Jan. 23, 2018, 9:57 AM), https://www.huffingtonpost.com/ entry/opinion-hopkins-gymnastics-nassar_us_5a673cfce4b0e5630073862f (discussing the wide variety of women abused by Nassar).

84. See, e.g., Joan Ryan, Larry Nassar Is Just the Beginning. Gymnastics Culture Has Been Abusive for Decades, NBC News (Jan. 22, 2018, 3:17 PM), https://www.nbcnews.com/think/opinion/larry-nassar-just-beginning-gymnastics-culturehas-been-abusive-decades-ncna840001; see also Steven Romo, Expert: Nassar Abuses Tip of the Iceberg for Gymnastics Problems, ABC (Jan. 24, 2018), http://abc13.com/expert-nassarabuses-tip-of-the-iceberg-for-gymnastics-problems/2985927/ (each discussing the conditions in gymnastics culture that made it conducive to abuse).

85. Char Adams, USA Gymnastics Cuts Ties with Karolyi Ranch Amid Sex Abuse Scandal: Our 'Priority Is Our Athletes', PeOPLE (Jan. 18, 2018, 5:29 PM), http://people.com/ sports/usa-gymnastics-karolyi-ranch-larry-nassar/; see Alice Park, Why It's a Big Deal that USA Gymnastics Is Cutting Ties with the Karolyi Ranch, Time (Jan. 18, 2018), http://time.com/5108887/usa-gymnastics-sexual-abuse-karolyi-ranch/; see also Lauren Gibbons, Nassar Victim Says Gymnastics Ranch Was 'Perfect Place for Abusers and Molesters,' MLive (Jan. 23, 2018), http://www.mlive.com/news/index.ssf/2018/01/ nassar_victim_says_she_tried_f.html (each discussing how the Karolyi Ranch helped perpetuate Nassar's abuse due to lack of supervision and a harsh, strict culture). 
and a listening ear. ${ }^{86}$ As former U.S. national champion and victim of Nassar, Jessica Howard, put it, "[Nassar] wasn't one of the scary people . . . you learn through all of your time in the gym that you need to listen and obey ... [Nassar] wasn't like that, he was very kind." ${ }^{87}$ As another victim stated, "Nassar used his charm and his position as national team doctor to make everyone his gossip buddy, his special friend, his best pal-so that when the world he built one day came crumbling down, he'd have an army of supporters defending him." 88

Numerous former gymnasts and Olympians have now spoken out about the culture of silence that permeated USAG and allowed not only Nassar's sexual abuse to persevere, but also consistent mental and emotional abuse inflicted by coaches as part of such intensive training to become the norm. ${ }^{89}$ In this way, a "tone at the top" was created with only one goal in mind - getting the girls to the Olympics, with little regard for how they got there. As one source stated:

[t]here is no other sport in which this could have happened but gymnastics ... [t] hese girls are groomed from an incredibly young age to deny their own experience. Your knee hurts? You're being lazy. You're hungry? No, you're fat and greedy. They are trained to doubt their own feelings, and that's why this could happen to over 150 of them. ${ }^{90}$

In such an environment, the athletes were completely silenced and if they did decide to tell someone about the pain and abuse inflicted against them, they were told not to complain. ${ }^{91}$

Dominique Moceanu, a 1996 gold-medal Olympian who was fortunate to have avoided Nassar's sexual abuse, was one of the first former gymnasts to publicly speak out about USAG's "egregiously flawed and dangerous system" that blatantly

86. Senate Hearing, supra note 45 (statements of victims Jamie Dantzscher, Jessica Howard, and former Olympian gold medalist Dominique Moceanu); see also Hopkins, supra note 83 (discussing the wide variety of women abused by Nassar) (quoting Lindsey Lemke, another one of Nassar's victims, who trained at the Twistar gym club); see also 20/20 Sister Survivors, supra note 39; see also Nassar's Exploitation of the Climate of Fear at a USA Gymnastics Training Site, NPR (Jan. 27, 2018, 5:48 PM), https://www.npr.org/ 2018/01/27/581343560/nassar-s-exploitation-of-the-climate-of-fear-at-a-usa-gymnasticstraining-site (discussing how the culture of gymnastics contributed to years of silence and fear); see also Freeman, supra note 38 ("Nassar's trial has shone a light on a mentality in the sports world that values performance over protection, medals over morals, and this has long been a concern about the gymnastics world.").

87. Senate Hearing, supra note 45, at 1:21:41 (statements of victim Jessica Howard); see also Hopkins, supra note 83 (quoting Lindsey Lemke, another one of Nassar's victims, who trained at the Twistar gym club); see also 20/20 Sister Survivors, supra note 39.

88. Hopkins, supra note 83.

89. See Schonbrun \& Hauser, supra note 50.

90. Freeman, supra note 38 (quoting Joan Ryan, author of a 1996 book that reveals the intense psychological and physical strain that female gymnasts in the U.S. suffer); see also JoAn Ryan, LitTle Girls in Pretty Boxes: The Making and Breaking of Elite GyMnASTS AND Figure SKATERS (1st ed. 1996).

91. See infra notes 92-97. 
ignored any concerns of its athletes and established a "culture that set the stage for other atrocities to occur." ${ }^{\prime 92}$ Revealing the years of mental and emotional abuse that she endured from coaches and trainers while working towards the Olympics, Moceanu described USAG as a "culture of fear, intimidation, and humiliation" largely established by head USAG coaches, Marta and Bela Karolyi. ${ }^{93}$ As Moceanu explains, the Karolyis defected to the United States from Romania in the early 1980s, taking with them the rigors of a "Communist, centralized system" and applying it to USAG as their training methodology with "total control with little to no oversight from any governing body," thereby perpetuating a true culture of silence that facilitated various types of abuse. ${ }^{94}$ "USAG openly frowned upon, ostracized, and punished those who dare speak out about anything that could be construed as critical of the program, even physical injury." ${ }^{95}$ As an example, Moceanu explains that, at age 14, her coaches told her to ignore severe leg pain she had been experiencing and continue training "over and over until [she] collapsed on the floor in the gym" - only then did coaches finally call for medical assistance to discover that Moceanu had been training on a broken leg. ${ }^{96}$ For those engaged in elite and Olympic training, female athletes of all ages, including children, were required to reside at the Karolyi Ranch "for days or weeks at a time without supervision of parents or other adults not employed by [USAG]," thereby perpetuating an environment of repression, which, "coupled with fear of retribution for speaking out, opened the door for sexual abuse to occur." ${ }^{\prime 7}$

One of Nassar's victims, Jamie Dantzscher, a 2000 U.S. Olympic bronze medalist, expressed that she was sure that the other adults at Karolyi Ranch had to be aware of Nassar's abuse given the circumstances of how his medical care was administered there-if the athletes were injured, it was mandatory to receive Nassar's medical treatments, even "after the lights were out in the gym and the training area was closed [for the day] ... the only other area to get [Nassar's] treatment was in our own room and the other adults never supervised that." 98 Dantzscher claimed that the "very least" other adults or coaches could have done was to supervise "a grown man" alone with a girl receiving "treatment" in her private room and in "[her] own bed" or even to have "one conversation [with the girls] about what is appropriate and what's not and [bring] more awareness to the issue." 99 As

92. Senate Hearing, supra note 45, at 0:42:59 (statement of Dominique Moceanu).

93. Id. at 0:43:38 (statement of Dominique Moceanu). The Karolyis were often named "the most powerful people in [USAG]." Id.

94. Id. at 0:43:46 (statement of Dominique Moceanu).

95. Id. at 0:44:09 (statement of Dominique Moceanu).

96. Id. at 0:44:19 (statement of Dominique Moceanu).

97. Id. at 0:44:52 (statement of Dominique Moceanu) (emphasis added); see also Tracy Connor, USA Gymnastics Abandons Karolyi Ranch Amid Sex-Abuse Scandal, NBC NEws (Jan. 19, 2018, 6:32 AM), https://www.nbcnews.com/news/us-news/usa-gymnasticsabandons-karolyi-ranch-amid-sex-abuse-scandal-n838876 (discussing the various conditions of the Ranch that perpetuated a culture of abuse against the athletes).

98. Senate Hearing, supra note 45, at 1:21:40 (statement of Jamie Dantzscher).

99. Id. at 1:22:21 (statement of Jamie Dantzscher); see also Nassar's Exploitation of the Climate of Fear at a USA Gymnastics Training Site, supra note 86 ("abuse [at Karolyi Ranch] became normalized"). 
expressed by these women and so many of Nassar's victims, no actions were taken within USAG culture to probe into any concerns or even acknowledge that the environment was not conducive to healthy and productive physical training or emotional well-being. Many claimed that this culture was actually why the U.S. Gymnastics team had been so successful for so many years. ${ }^{100}$

\section{Lack of Adequate Internal and External Reporting Channels}

As is now clear from the personal accounts of abuse from Nassar's victims, as well as parents, friends, and others within the gymnastics community who have now come forward, proper reporting channels to raise and escalate concerns regarding abuse simply did not exist within USAG or MSU, Nassar's two employers. ${ }^{101}$ These reporting channels were lacking on both an internal and an external level. ${ }^{102}$ Although, as discussed, many of the young women had not realized they were abused until public reports emerged later, some victims did tell others in the community their concerns about Nassar's "treatments," but all were met with silence and told that Nassar was nothing but a respected and skilled doctor. ${ }^{103}$

Because Nassar had developed so many strong friendships and so much respect from his professional colleagues at MSU, within USAG, and in the gymnastics community generally, nobody with any power to stop him questioned his behavior; to the contrary, the adults who did receive complaints from the athletes defended his behavior because they were blindly convinced that he would provide nothing but optimal, legitimate treatment. ${ }^{104}$ In one instance in 1997, then 16-yearold Larissa Boyce, a gymnast at MSU's youth program, and the "first known person"

100. See, e.g., Alice Park, Inside Camp Karolyi: Building the U.S. Women's Olympic Gymnastics Team, TIME (July 16, 2012), http://olympics.time.com/2012/07/16/ camp-karolyi-how-and-why-martha-karolyi-defines-u-s-womens-gymnastics/ (describing how the strictness and remoteness of the Karolyi Ranch has helped facilitate making the U.S. women's gymnastics team "among the most successful in the world."); see also Meyers, supra note 16 (discussing how the culture of the Karolyi Ranch led to U.S. women's gymnastics earning international recognition).

101. See, e.g., Carron J. Phillips, Aly Raisman Right to Call Out USA Gymnastics for Lack of Response to Sexual Abuse Scandal, DAILy NEws (Aug. 22, 2017, 1:31 AM), http://www.nydailynews.com/sports/more-sports/aly-raisman-call-usa-gymnastics-lackresponse-article-1.3429931; Deborah J. Daniels, Report to USA Gymnastics on Proposed Policy and Procedural Changes for the Protection of Young Athletes, KRIEG DeV Ault LLP, 62-67 (June 26, 2017), https://usagym.org/PDFs/About\%20USA\%20Gymnastics /ddreport_062617.pdf; see also Senate Hearing, supra note 45 (statements of the former gymnasts).

102. See, e.g., Phillips, supra note 101; Daniels, supra note 101; see also Senate Hearing, supra note 45 (statements of the former gymnasts).

103. Emily Lawler, What Was Portrayed as Medical Treatment, Alleged Victims Claim Is Sexual Assault, MLive (Feb. 8, 2017), http://www.mlive.com/news/index.ssf/ 2017/02/what_was_portrayed_as_medical.html.

104. See Tracy Connor, Larry Nassar's Attorney Doesn't Believe All Accusers Were Abused, NBC NEws (Feb. 1, 2018, 5:06 PM), https://www.nbcnews.com/news/usnews/larry-nassar-s-attorney-doesn-t-believe-all-accusers-were-n843696 ("Many who knew him as a respected sports medicine specialist at Michigan State University and the team doctor for USA Gymnastics defended him.”). 
to have raised concerns about Nassar internally, told MSU head gymnastics coach Kathie Klages (a close friend of Nassar) about her discomfort with Nassar's methods. ${ }^{105}$ Rather than properly investigate these concerns or report them to a higher authority or to the police, Klages "humiliated and berated" Boyce, interrogating her about her accusations and leading her to believe that she had misunderstood a legitimate medical technique. ${ }^{106}$ Klages did inform Nassar of what Boyce had told her, but Klages chose to trust Nassar, who defended his methods as medically sound, over the young gymnast. ${ }^{107}$ Had this report been adequately addressed, Nassar could have been stopped as early as 1997. As these sad facts reveal, blaming and silencing Nassar's victims had become a common theme. ${ }^{108}$

Similar examples of the lack of proper internal and external reporting channels, illustrated through the minimization of red flags and the lack of any investigation, have emerged widely. ${ }^{109}$ Dismissive responses by coaches, trainers, and other professionals to whom the women reported include some of the following: (1) "Nassar [is] a respected doctor and [you] should trust him" (response to Christie Achenbach, former runner, by her coach); (2) "[H]e's a world-renowned doctor ... [who] treats elite athletes" (response to Tiffany Lopez, former softball player, by her trainers); (3) trainer of Jennifer Rood Bedford, former volleyball player, told Bedford she would need to make an official statement that "what Nassar had done was unprofessional or criminal" in order to proceed with looking into the matter, which Bedford decided not to pursue due to embarrassment; and (4) Kyle Stephens, whose parents were very close friends of Nassar and who was as young as six-years old when Nassar molested her in his own home, told her psychologist about the abuse in 2004, who never reported the allegations, and her parents chose to believe Nassar over her (which later led her father to commit suicide in 2016). ${ }^{110}$

In one instance, concerns were escalated within USAG's organizational structure but ultimately ignored. ${ }^{111}$ In 2015, Maggie Nichols, a member of the U.S. national gymnastics team, discussed her concerns about Nassar's treatments with

105. Tracy Connor \& Kathryn Berg, Larry Nassar's Victims Now Focused on MSU, USA Gymnastics, NBC NEws (Feb. 6, 2018, 9:28 AM), https://www.nbcnews.com/news/usnews/larry-nassar-s-victims-now-focused-msu-usa-gymnastics-n844871.

106. See id.; MLive, Survivor Reported Sexual Assault in 1997, MSU Did Nothing, YouTuBE 1:10 (Jan. 19, 2018), https://www.youtube.com/watch?v=OYJIx_3hbRA (victim statement of Larissa Boyce).

107. Connor \& Berg, supra note 105; MLive, supra note 106, at 3:25 (victim statement of Larissa Boyce); see also Nicole Chavez, What Others Knew: Culture of Denial Protected Nassar for Years, CNN (Jan. 25, 2018, 11:21 AM), https://www.cnn.com/2018/ 01/23/us/nassar-sexual-abuse-who-knew/index.html ("Boyce recalls Klages telling her that she could not imagine Nassar "doing anything questionable," then discouraging her from filing a formal complaint, according to a federal lawsuit.").

108. See Correa \& Louttit, supra note 36.

109. See Daniels, supra note 101; see also Associated Press, supra note 36.

110. Tracy Connor \& Sarah Fitzpatrick, Gymnastics Scandal: 8 Times Larry Nassar Could Have Been Stopped, NBC NEws (Jan. 28, 2018, 6:34 PM), https://www.nbcnews.com/news/us-news/gymnastics-scandal-8-times-larry-nassar-couldhave-been-stopped-n841091.

111. Id. 
another gymnast and was overheard by her coach, who reported it to officials at USAG. ${ }^{112}$ However, USAG never told law enforcement of this information and instead hired a private investigator, resulting in USAG's ultimate conclusion that there was no "reasonable suspicion" that Nassar had committed any crime. ${ }^{113}$

USAG's actions in attempting to hide these allegations against Nassar were particularly egregious. The organization placed any such reports about Nassar's behavior in a file cabinet rather than reporting the issues externally to any unbiased entity. ${ }^{114}$ As part of its 2015 internal investigation, USAG interviewed McKayla Maroney, 2012 Olympic gold medalist, who was abused by Nassar at the Karolyi Ranch and at international competitions (even within Nassar's own hotel room after giving her a sleeping pill on an international flight). ${ }^{115}$ It was only after Maroney's interview that USAG finally contacted the FBI about the alleged abuse and discretely fired Nassar-however, USAG failed to inform MSU of the abuse, where Nassar continued to see dozens of female patients, and also required Maroney to sign a confidentiality agreement in December 2016 as part of a $\$ 1.25$ million settlement that she had reached with USAG so that she would keep quiet about the scandal that had finally broke. ${ }^{116}$ Maroney has since given public interviews about the abuse she has suffered, revealing that Nassar abused her "hundreds" of times. ${ }^{117}$

In late 2016, USAG hired Indianapolis-based law firm, Krieg DeVault LLP, to conduct an independent review of USAG's policies, procedures, and practices for handling sexual misconduct matters going forward. ${ }^{118}$ Krieg DeVault partnered with Praesidium to conduct the report, an entity that specializes in "preventing sexual abuse in organizations that serve youth and vulnerable adults." 119

\section{2. $I d$.}

113. Id.

114. Rachael Denhollander, Victim Statement, Read Rachael Denhollander's Full Victim Impact Statement About Larry Nassar, CNN (Jan. 30, 2018, 7:34 AM), https://www.cnn.com/2018/01/24/us/rachael-denhollander-full-statement/index.html.

115. Connor \& Fitzpatrick, supra note 110; Abigail Abrams, 'I Thought I Was Going to Die': Read McKayla Maroney's Full Victim Impact Statement in Larry Nassar Trial, Time (Jan. 19, 2018), http://time.com/5109011/mckayla-maroney-larry-nassar-victimimpact-statement/.

116. Connor \& Fitzpatrick, supra note 110 (MSU police logs revealed that Nassar allegedly abused numerous additional women at his MSU clinic until the September 2016 newspaper story and subsequent investigation "that finally took him out of the examining room."); USA Gymnastics Won't Seek Fine if McKayla Maroney Discusses Abuse, ESPN (Jan. 17, 2018), http://www.espn.com/olympics/story/_id/22131861/usa-gymnastics-seekfine-mckayla-maroney-speaks-sexual-abuse (per the confidentiality agreement, Maroney faced a $\$ 100,000$ fine if she spoke out. USAG, at the very least, decided not to enforce this provision, thereby allowing Maroney to give her victim impact statement at Nassar's sentencing hearing).

117. Sarah Fitzpatrick \& Tracy Connor, McKayla Maroney Says Larry Nassar Molested her 'Hundreds' of Times, NBC News (Apr. 18, 2018, 8:32 PM), https://www.nbcnews.com/news/us-news/mckayla-maroney-says-larry-nassar-molestedher-hundreds-times-n866926.

118. See Daniels, supra note 101.

119. Id. at 2. 
As expected, the report revealed that USAG did not require its members to report suspected child abuse and lacked a system to ensure that its constituents and member clubs adhered to the membership requirements of the organization. This specifically highlights the need to create a strict reporting system for any violations and for USAG to respond promptly upon receipt of such information, especially in the case of physical, emotional and sexual abuse. ${ }^{120}$ The "overarching recommendation" of this report is for a "complete" cultural shift within the organization- "the culture that must be adopted is that USA Gymnastics' top priority is the safety and wellbeing of its athletes; not just their success on the field of play." ${ }^{21}$ An essential component of establishing this culture is the encouragement of reporting. As the report notes, "The Overall Environment Surrounding Competitive Gymnastics, and in Particular USA Gymnastics, Tends to Suppress Reporting," as there are "many barriers to reporting." 122

These barriers exist due to the following factors that are descriptive of the USAG environment: young age and emotional development of the gymnasts; lack of athletes' understanding as to wrongful acts; a "[s]trong desire to please authority figures"; the power imbalance of gymnastics; a culture of "mental toughness, no complaining"; concerns about the repercussions of reporting (including team selection and future scholarships); "ostracism of those who do complain"; and the belief that if an athlete does report, that it must be a written, signed complaint that will be shared with the abuser. ${ }^{123}$ The heartbreaking stories that have emerged from Nassar's victims revealed that all of these factors were at play within USAG, which was exacerbated by the lack of effective and widely advertised reporting within the organization. ${ }^{124}$

\section{Legal AND Structural Reform to Prevent ANOTher SeXual Abuse Tragedy in Organized U.S. SPORTS}

Although it is too late to undo the horrors of Nassar's abuse on a generation of American female gymnasts, there are reasonable reforms that USAG and other high-level national sports bodies can implement to minimize the possibility of another sexual abuse scandal reaching the magnitude of this tragedy. ${ }^{125}$ This section will propose two important structural and legal reforms conducive to reducing the risk of a sexual predator remaining undetected within the ranks of USAG or other

120. Id. at 7,87 (recommending that any failure to adhere to this reporting system should result in sanctions, including revocation of membership with USAG).

121. Id. at 7, 23, 87 (recommending that any failure to adhere to this reporting system should result in sanctions, including revocation of membership with USAG and noting that four aspects of effecting cultural change should include "[a] strong voice from the top of the organization, [c]lear standards of behavior, [the] [p]rovision of sufficient resources to assist in maintaining the standards; and [a]ccountability").

122. Id. at 84 (recommending that any failure to adhere to this reporting system should result in sanctions, including revocation of membership with USAG).

123. Id. at 84-85 (recommending that any failure to adhere to this reporting system should result in sanctions, including revocation of membership with USAG).

124. See, e.g., Carrea \& Louttit, supra note 36.

125. See infra notes 126-210 and accompanying text. 
organized sports bodies again. Section III.A proposes a whistleblower protection system to encourage the reporting and investigation of alleged wrongdoing within athletic bodies, such as USAG, and the protection from retaliation for anyone who comes forward with such information. Section III.B then proposes the unionizing of elite U.S. women's gymnasts for purposes of providing them with representatives that operate under the formal legal duty to represent the gymnasts' best interestsand not the interests of USAG, their coaches, or even, in some cases, their overbearing and glory-obsessed parents.

\section{A. Whistleblower Protection Systems}

One necessary component of any meaningful structural reform to USAG would include the implementation of a robust whistleblowing policy, along with adequate assurances as to its effectiveness and utilization. ${ }^{126}$ Interestingly, USAG actually has a whistleblower policy on the books, which is dated August 2014, and thus was created three years before Nassar's abuse finally came to light. ${ }^{127}$ This policy, although brief and clearly not enforced, implements a reporting requirement which states that "it is the responsibility of all directors, officers, and employees to report [to a designated individual] a violation or suspected violation of the Bylaws, the Code, applicable policies or procedures of [USAG], or accounting practices, laws or regulations that govern the operations of [USAG] (collectively "Violations") . . . ."128

The policy also includes an anti-retaliation component, stating that "no director, officer, or employee ('Reporting Person'), who in good faith, reports a Violation, shall suffer harassment, retaliation or any adverse employment consequence, including, but not limited to, termination, suspension, compensation decreases, poor work assignments and/or threats of any nature"-anyone who retaliates against a "Reporting Person" in violation of this policy is subject to discipline. ${ }^{129}$ The policy then states that USAG has "an open door policy" and that concerns should be shared with the entity's president or another member of senior management, who is then required to report violations to a designated "USAG Compliance Officer." 130 This internal compliance officer is then responsible for reviewing reports and determining necessary next steps. ${ }^{131}$ Other noteworthy items within the policy state that the whistleblower who files a complaint with respect to

126. See Jeanette Ashton, 15 Years of Whistleblowing Protection under the Public Interest Disclosure Act 1998: Are We Still Shooting the Messenger?, 44 InDUS. L.J. 29, 46 (2015) (noting that a whistleblowing policy means very little if it is not supported by a culture of transparency and by the organization); Jennifer M. Pacella, Inside or Out? The Dodd-Frank Whistleblower Program's Antiretaliation Protections for Internal Reporting, 86 TEMP. L. REV. 721, 750-52 (2014) (discussing the importance of strong whistleblower retaliation policies).

127. USA Gymnastics Whistleblower Policy, USA GyMnASTICS (Aug. 2014), https://usagym.org/PDFs/About\%20USA\%20Gymnastics/Governance/whistleblowerpolicy. pdf.

128. Id. II 2 .

129. Id. $\llbracket 3$.

130. Id. II 4,5 .

131. Id. I 5 . 
a violation "must be acting in good faith and have reasonable grounds for believing the information disclosed indicates a [v]iolation" and that the whistleblower's report will be kept confidential "to the extent possible, consistent with the need to conduct an adequate investigation." 132

Without more, the fact that USAG has a whistleblowing policy on the books is of little comfort. Any whistleblowing (or good governance) policy is simply not enough if the organization that it governs fails to encourage reporting without fear of reprisal. ${ }^{133}$ It has now become clear through the testimony of hundreds of Nassar's victims that protection from reprisal for speaking out about any known abuse, let alone even any red flags, was severely lacking. Furthermore, any whistleblowing policy should be adequately advertised and disseminated to all constituents of an organization. ${ }^{134}$ Much to the surprise of many, Enron, an entity whose demise resulted from one of the most colossal governance failures in corporate history, also had in place a code of conduct, a compliance program, and set of core values (respect, communication, integrity, and excellence), each intended to promote ethical behavior within the organization. ${ }^{135}$ These policies failed and Enron deteriorated in large part due to the nonenforcement of these policies and programs, a lack of oversight by its board of directors, and various conflicts of interest within the entity. ${ }^{136}$ In much the same way, USAG's whistleblower policy has failed in actual practice.

The best facilitator of encouraging whistleblowers to come forward is the development of a culture that embraces such individuals and makes them feel as though their report will be valued and not used against them. ${ }^{137}$ The culture within USAG is in need of a complete overhaul and needs to emphasize, in both theory and actual practice, that the safety and well-being of its athletes is a top priority and that any information that would threaten this goal in any way, however minor, should be brought to the attention of leaders within the organization and ultimately to the board of directors. ${ }^{138}$ An additional facilitator of a healthy culture emphasizing reporting

132. Id. II 7, 8 .

133. See Pacella, supra note 126, at 754-56 (discussing how to encourage internal reporting by whistleblowers and the benefits of such reporting).

134. Bruce D. Collins, Part II Whistleblower and Conflict of Interest Policies, Georgetown U. L. Ctr. Continuing Legal Educ., 2004 WL 2800537 at*3 (Apr. 2004).

135. Charles Barnes, Why Compliance Programs Fail: Economics, Ethics and the Role of Leadership, 19 HEC F. 109, 109-10 (2007) (discussing Enron and the organization's disregard for adhering to its core values in actual practice).

136. Id. ("Enron appeared for all the world to be an organization that tried to be a good corporate citizen and adhered to the highest ethical standards."); see also GEOFFREY P. Miller, The Law of Governance, Risk Management, and Compliance 517-18 (2014) (discussing Enron's downfall despite the company "appear[ing] to be a cutting-edge compliance shop.").

137. See John Ashcroft et al., Whistleblowers Cash In, Unwary Corporations Pay, 40 Hofstra L. REv. 367, 407 (2011) (discussing the importance of culture in encouraging internal whistleblowers to report); see also Pacella, supra note 126, at 754-57 (discussing ways in which whistleblowers can be motivated to come forward).

138. See Daniels, supra note 101, at 23, 38 (suggesting that to achieve the "complete cultural change" that it needs, USAG must focus on its leadership, specifically the 
should consist of various forms of education within USAG, ideally in the form of mandatory trainings, to ensure that girls of all ages, especially minors, as well as parents and coaches, are fully aware of what constitutes sexual abuse versus legitimate medical treatment and what is appropriate in all of the gymnasts' interactions with adults, including medical professionals and coaches who are in a superior position of trust over the gymnasts.

Even if USAG's existing whistleblowing policy had been effectively administered or enforced, the policy contains several weaknesses that fail to create an optimal whistleblowing system that would encourage reports of abuse or misconduct of any type and the prompt management of them. ${ }^{139}$ First, the policy makes absolutely no mention of the gymnasts themselves - the individuals who, at least in theory, are those that the policy ultimately seeks to protect. ${ }^{140}$ It provides no retaliation protections for the gymnasts and imposes no reporting obligations on them. ${ }^{141}$ In addition, other essential individuals are completely absent from reporting obligations, including coaches (those with the most constant and intimate access to the gymnasts) and member clubs, which are the only entities that may apply for membership with USAG on behalf of an athlete. ${ }^{142}$ USAG's current whistleblowing policy's reporting requirement is limited to a narrow subset of individualsdirectors, officers, or employees - who are not likely to be aware of the existence of abuse or other wrongdoing given their removal from the rigors of everyday training and interaction with the athletes. ${ }^{143}$ At a minimum, the gymnasts themselves, coaches, and member clubs must be included among those with reporting obligations, and they must be eligible for the policy's retaliation protections for reporting. The gymnasts themselves should be included in this category because they are the most probable individuals to become aware of abuse or other misconduct, either because they were the actual victims or because they heard about wrongdoing through their close friendships with their fellow gymnasts. ${ }^{144}$ Although it may be difficult for the gymnasts to feel comfortable making such a report given

board of directors and president, in permeating the message that it is committed to protecting athletes above all else to its constituents, the field, and the clubs hosting member coaches, instructors, and athletes). In the wake of the Nassar scandal, the U.S. Olympic Committee gave USAG the ultimatum of having all 20 of its directors resign or lose its status as a sports governing body. See David Close \& Nicole Chavez, Olympic Committee Gives USA Gymnastics Board 6 Days to Resign, CNN (Jan. 26, 2018, 9:30 AM), https://www.cnn.com/2018/01/26/us/usoc-orders-usa-gymnastics-resignations/index.html (quoting CEO of U.S. Olympic Committee, Scott Blackmun, "Our position comes from a clear sense that USAG culture needs fundamental rebuilding."). As such, initial steps to completely revamp the culture within USAG have hopefully begun.

139. See infra notes 140-43.

140. USA Gymnastics Whistleblower Policy, supra note 127.

141. Id. (only directors, officers, and employees are required to report and are provided with retaliation protections).

142. 2019/20 Member Registration How to Guide, USA GyMnASTICS, https://usagym.org/PDFs/Member\%20Services/howtoguide.pdf (last visited July 31, 2019) (outlining the mechanisms of applying for membership to USAG).

143. See supra Section II.A.

144. See supra Part II. 
their personal circumstances, unless the abuse comes to light it cannot be stopped. There are, however, various ways to mitigate this discomfort, including reports through an anonymous whistleblower hotline ${ }^{145}$ and a fundamental shift in culture in which transparency, especially as it relates to any allegation of abuse, is the norm. Additionally, a commitment to antiretaliation of whistleblowers must be enforced and echoed throughout the entire organization.

Second, the retaliation protections in USAG's whistleblowing policy are problematic in that they focus on adverse employment actions as a main form of retaliation to be protected against, specifically noting examples of retaliation that may include "termination, suspension, compensation decreases, poor work assignments and/or threats of any nature." 146 This provision should be amended to include the various forms of retaliation that are most applicable to the actual gymnasts as nonemployees of USAG including, most importantly, the form of retaliation that so many of the victims feared the most-loss of their coveted spot on the national or Olympic-bound teams, removal from Olympic training, or the loss of their coaching and mentoring relationships. ${ }^{147}$ Including actual forms of plausible retaliation against athletes ensures that those in the best position to report are encouraged to do so without fear of reprisal.

Various studies have revealed that the most significant deterrent to individuals considering blowing the whistle is fear of retaliation by peers, colleagues, or supervisors, which is often fueled by an organizational culture of silence or disregard. ${ }^{148}$ Whistleblowers commonly experience a devastating fate

145. See, e.g., Ashcroft et al., supra note 137, at 401 ("[a] hotline is one of the least expensive yet most effective ways for corporations to encourage internal whistleblowing and discover possible wrongdoing."); Bill Libit, Elements of an Effective Whistleblower Hotline, HARV. L. Sch. Forum ON CORP. Governance \& Fin. Reg. (Oct. 25, 2014), http://corpgov. law.harvard.edu/2014/10/25/elements-of-an-effective-whistleblower-hotline/ (noting that effective whistleblower hotlines are crucial to an entity's fraud detection methods); Richard Moberly, Sarbanes-Oxley's Whistleblower Provisions: Ten Years Later, 64 S.C. L. REv. 1, 18 (2012) (discussing the emergence of whistleblower hotlines as established widely in the U.S. through the Sarbanes-Oxley Act of 2002).

146. USA Gymnastics Whistleblower Policy, supra note 127, 【 3.

147. See, e.g., Senate Hearing, supra note 45, at 0:50:50 (statement of Jamie Dantzscher that "I felt like if I said anything about that abuse, they were in control of taking my dream away in a second."); Tim Evans, Marisa Kwiatkowski \& Mark Alesia, Dominique Moceanu Says USA Gymnastics CEO 'At the Forefront' of Ignoring Abuse, INDYSTAR (Feb. 26, 2017, 6:02 AM), https://www.indystar.com/story/news/investigations/2017/02/26/ dominique-moceanu-says-usa-gymnastics-ceo-forefront-ignoring-abuse/98258474/ (last updated Mar. 22, 2017, 3:12 PM) (former Olympian gymnast Dominique Moceanu discusses the repercussions that gymnasts within USAG feared for speaking out against abuse).

148. See, e.g., David M. Mayer et al., Encouraging Employees to Report Unethical Conduct Internally: It Takes a Village, 121 Org. Behav. \& Hum. Decision Processes 89, 100 (2013) (noting that fear of retribution is one of the major factors that disincentivizes whistleblowers from coming forward); Matt A. Vega, Beyond Incentives: Making Corporate Whistleblowing Moral in the New Era of Dodd-Frank Act "Bounty Hunting," 45 ConN. L. REV. 483, 512-14 (2012) (noting that fear of retaliation results in a "chilling effect" on whistleblowers given the social and psychological components of such fear); Moberly, supra 
once they have reported, which is largely believed to be due to the psychological phenomenon of "groupthink" in which members of a group tend to conform their thinking to align perspectives while focusing on the positives of group behavior and minimizing any negative aspects - in this way, the whistleblower, who essentially dissents from the group mentality, is usually met with resistance from other group members and from those to whom the whistleblower reported. ${ }^{149}$ Groupthink clearly manifested itself as twofold within the gymnastics culture-first, as too accepting of the harsh training conditions of the sport and dismissive of the mental and emotional anguish associated therewith, and, second, as resistance to the reality that Nassar, rather than embodying the principles of the esteemed doctor that he was believed to be, was actually a pedophile. ${ }^{150}$ This resistance was perpetuated by the notion that his "treatments" were actually legitimate medical procedures. ${ }^{151}$ The vulnerability of the women and girls in his care made this possible - they came to him when injured and in much pain, deferring to his medical expertise and stellar reputation in the community, and, although never giving consent for the "treatments," trusting in his assurances that his behavior was legitimate. ${ }^{152}$ The women and girls were "uniquely vulnerable. They were in pain from injuries. They were told Dr. Nassar was the only one who could heal them. As top athletes, they were used to taking orders-they were programmed for obedience." 153 As victim Jamie Dantzscher explained, "[t]hey wanted robots and it was survival of the fittest and if you didn't survive, then see you later, you're not on the team." 154

To combat the perils of groupthink within USAG, especially among the adults to whom some of the women did report, the organization's whistleblowing policy should provide retaliation protections not only for internal reporting, but for

note 145, at 44-45 (discussing studies revealing that strong ethical cultures encourage individuals to blow the whistle; "people - not necessarily policies and codes-create and perpetuate that culture ....”); ETHICS Res. CTR., RETALIATION: THE COST TO Your COMPANY AND ITS EMPLOYEES 1 (2010) (noting fear of retaliation is the "leading indicator of misconduct ... .").

149. James A. Fanto, Whistleblowing and the Public Director: Countering Corporate Inner Circles, 83 OR. L. REV. 435, 443-44, 463-67 (2004) (discussing the groupthink psychological theory by Irving Janis and its connection to whistleblowing); see also David B. Greenberger, Marcia P. Miceli \& Debra J. Cohen, Oppositionists and Group Norms: The Reciprocal Influence of Whistle-blowers and Co-workers, 6 J. Bus. ETHICs 527, 536 (1987) (describing how whistleblowers, who challenge conformity, often face rejection from peers and colleagues who "see themselves as more similar to each other than to the [whistleblower] deviant").

150. See supra Part II.

151. See id.

152. Team USA Doctor Allegedly Masked Sexual Abuse as Treatments, CBS (Feb. 17, 2017), https://www.cbsnews.com/news/team-usa-doctor-allegedly-disguised-sexualabuse-as-treatments/ (former gymnast and victim Jessica Howard on Nassar's "treatments": "II remember thinking something was off but I didn't feel like I was able to say anything because he was, you know, this very high profile doctor' ... [ [t]he girls questioned Nassar's behavior among themselves ...' [they] would say 'yeah he touches you funny,' she recalls.”).

153. 20/20: Sister Survivors, supra note 39, at 12:40 (emphasis added).

154. Id. at 12:54 (statement of victim Jamie Dantzscher). 
external reporting as well. While internal whistleblowing is enormously beneficial to any organization, ${ }^{155}$ whistleblowers who report in this manner are usually faced with numerous disincentives that an external whistleblower reporting to outside sources would not normally face, such as mental or physical retaliation for shedding light on negative information about their peers or leaders or more subtle forms of retaliation such as ostracism, exclusion from social events, silent treatment, loss of friendships, or heightened scrutiny. ${ }^{156}$ In most organizational settings, internal whistleblowing within the entity is preferable and merits the strongest retaliation protections, as it reveals misconduct or perceived violations of the law in their early stages and at a time that the organization can timely address the concerns and avoid future damage associated with letting the misconduct continue while avoiding possible governmental intervention. ${ }^{157}$ In the case of USAG, however, it is just as important to implement a policy that would protect external whistleblowers from retaliation if they report to outside sources such as law enforcement, the media, the U.S. Olympic Committee, or the Fédération Internationale de Gymnastique. ${ }^{158}$ USAG's existing whistleblowing policy makes absolutely no mention of external reporting or retaliation protections for that type of reporting. ${ }^{159}$ To properly address any future instances of sexual or other physical abuse, it is essential to ensure that there is an antiretaliation policy for reports to an external source and to specifically encourage reports to law enforcement so that the perpetrator can be charged from a criminal standpoint.

With respect to retaliation protections for internal and external reporting alike, it is also crucial to establish which type of standard would serve as the threshold to trigger eligibility for retaliation protections as it pertains to the

155. Pacella, supra note 126, at 757-60 (discussing the numerous benefits of internal whistleblowing); Norman D. Bishara, Elletta Sangrey Callahan \& Terry Morehead Dworkin, The Mouth of Truth, 10 N.Y.U. J.L. \& Bus. 37, 76 (2013) (discussing the benefits of internal whistleblower reports).

156. See, e.g., Bishara, et al., supra note 155, at 97-98 (describing the various forms of retaliation against whistleblowers as "ostracism, isolation, blacklisting, defamation, job stagnation, and personal consequences such as depression and family problems"); FREDERICK D. Lipman, Whistleblowers: Incentives, Disincentives, and Protection Strategies 57-61 (2012) (discussing the various disincentives to internal whistleblowing); Pamela $\mathrm{H}$. Bucy, Private Justice, 76 S. CAL. L. Rev. 1, 61 (2002) ("It is difficult emotionally, personally, intellectually and professionally to come forward and blow the whistle on one's employer, colleagues and friends.").

157. See, e.g., Justin Blount \& Spencer Markel, The End of the Internal Compliance World As We Know It, or an Enhancement of the Effectiveness of Securities Law Enforcement? Bounty Hunting under the Dodd-Frank Act's Whistleblower Provisions, 17 FORDHAM J. CORP. \& FIN. L. 1023, 1060 (2012) (discussing that open lines of communication facilitate early reporting of problems, which can be addressed before the problem becomes unmanageable); Lucian E. Dervan, Responding to Potential Employee Misconduct in the Age of the Whistleblower: Foreseeing and Avoiding Hidden Dangers, 3 BLOOMBERG CORP. L.J. 670, 674 (2008) (internal whistleblowing usually allows organizations to take corrective action in a timely and efficient manner).

158. See AbOUt USA Gymnastics, supra note 6.

159. See USA Gymnastics Whistleblower Policy, supra note 127. 
whistleblower's belief that some type of violation has occurred. Most whistleblowing statutes utilize the "reasonable belief" standard, whereby eligibility for retaliation protections requires that the whistleblower must have reasonably believed that the information reported constituted a possible violation of law-if it is the case that no violation of the law has actually occurred but that the whistleblower was still retaliated against because of the report, retaliation protections are still available as long as this standard is met. ${ }^{160}$ The reasonable belief standard requires both subjective and objective elements, which require that the whistleblower has a subjectively genuine, good faith belief that the issue of concern is demonstrative of a possible violation of the law and an objective belief that a similarly situated person with a comparable background and skill set would also believe a violation to have occurred. ${ }^{161}$

Although the reasonable belief standard is commonly applied in statutory whistleblower protections and is considered to be one of the more lenient eligibility thresholds, ${ }^{162}$ a whistleblower program requiring only a subjective component is the most lenient since it concerns itself only with the personal circumstances of the whistleblower, who is eligible for retaliation protections in all cases except when knowingly making a false report. ${ }^{163}$ In contrast, when objectivity is needed, the whistleblower is judged against the "reasonable person" standard to determine whether someone with the same factual circumstances, knowledge, background, and

160. See, e.g., Sarbanes-Oxley Act, 18 U.S.C. § 1514A(a)(1) (2012); Dodd-Frank Act, 17 C.F.R. § 240.21F-2(b)(1)(i) (2011); Fair Labor Standards Act, 29 U.S.C. § 218c(a)(2) (2010) (each applying the "reasonable belief" standard); see also David Orozco, Amending the Economic Espionage Act to Require the Disclosure of National Security-Related Technology Thefts, 62 CATH. U. L. REV. 877, 909 (2013) (discussing the widespread use of the "reasonable belief" standard in statutes providing whistleblower retaliation protections); see Wiest v. Lynch, 710 F.3d 121, 132-33 (3d Cir. 2013) (explaining that whistleblowers are still protected from retaliation even if there is ultimately no violation of the law). Case law has also interpreted federal whistleblowing statutes that do not explicitly state the reasonable belief standard as requiring such a standard. See, e.g., Fanslow v. Chicago Mfg. Ctr., 384 F.3d 469, 480 (7th Cir. 2004) (agreeing with other circuit courts that the reasonable belief standard applies to determine whistleblower retaliation protections under the False Claims Act); Knox v. U.S. Dep't of Labor, 232 Fed. Appx. 255, 258-59 (4th Cir. 2007) (applying the reasonable belief standard to the Clean Air Act).

161. See Allen v. Admin. Review Bd., 514 F.3d 468, 477 (5th Cir. 2008) (explaining the objective component of the reasonable belief standard); Securities Whistleblower Incentives and Protections, 76 Fed. Reg. 34,300, 34,303 (June 13, 2011) (codified at 17 C.F.R. 240, 249) (discussing the subjective component of the reasonable belief standard, under which motive of the whistleblower is not required).

162. See, e.g., United States v. Porter, 594 F.3d 1251, 1258 (10th Cir. 2010) (finding that the reasonable belief standard offers more leniency than the "probable cause" standard); Shelby A.D. Moore, Doing Another's Bidding under a Theory of Defense of Others: Shall We Protect the Unborn with Murder?, 86 KY. L.J. 257, 275 (1998) (discussing how a "reasonable belief" rule is a more lenient standard).

163. David Culp, Whistleblowers: Corporate Anarchists or Heroes? Towards A Judicial Perspective, 13 HofSTRA LAB. L.J. 109, 130 (1995); Jessica Ann Toth Johns, Mandated Voices for the Vulnerable: An Examination of the Constitutionality of Missouri's Mandatory Child Abuse Reporting Statute, 72 UMKC L. REV. 1083, 1094 (2004). 
experience would also have believed the conduct constitutes a violation of the law. ${ }^{164}$ The need to satisfy the objectivity component would be another hurdle for the whistleblower to overcome to qualify for protection. The USAG whistleblowing policy takes a step in the right direction by providing retaliation protections for those who report "in good faith," 165 thereby implying subjectivity, but the policy should clearly articulate this distinction and ensure that a "reasonable belief" standard is not applicable, especially as it pertains to all enumerated individuals with reporting obligations, most notably the gymnasts. The gymnasts, many of whom are minor children, should not be judged against each other when determining whether retaliation protections for a report they make are warranted — only their individual mental state when making the report should be considered, which is most appropriate in light of their vulnerability as children or young women, the intense physical and mental pressures that they are up against during training, and their position of subordination to coaches, trainers, and other adults in positions of superiority within the gymnastics community. ${ }^{166}$

An additional weakness in USAG's whistleblowing policy involves the way in which reports are received and handled. An individual known as a "USA Gymnastics Compliance Officer" is tasked with the duty of ultimately receiving the whistleblower's report from senior management, reviewing it, and as vaguely stated, "determining the steps to be taken to investigate and seek resolution of all reported complaints ...." ${ }^{\prime 67}$ This compliance officer may then advise the president, the audit committee, or both "at his/her discretion" in the process of managing the reports. ${ }^{168}$ There are several problems with this model. First, this compliance officer is neither named in the policy nor is there a reference to how such a person may be contacted. ${ }^{169}$ It is not known whether such an officer was actually even appointed at the time of this policy's creation, has since been appointed, or was already in existence. Any potential whistleblower referring to USAG's policy in advance, perhaps when contemplating whether to blow the whistle or not, would not be able to confirm that some individual will ultimately manage and properly address the report, let alone know how to contact that person. A thorough search on the internet,

164. Erhart v. BofI Holding, Inc., 269 F. Supp. 3d 1059, 1072 (S.D. Cal. 2017); Allen, 514 F.3d at 477.

165. USA Gymnastics Whistleblower Policy, supra note 127, I 3.

166. By way of comparison, under tort law, the subjective standard (as opposed to the "reasonable person" standard) applies to children and those with mental or physical disabilities when determining questions of liability. See John C.P. Goldberg, What Nobody Knows, 104 Mich. L. REV. 1461, 1491 n.65 (2006) (noting that the subjective standard applies to young children); Jacob E. McKnite, When Reasonable Care Is Unreasonable: Rethinking the Negligence Liability of Adults with Mental Retardation, 38 WM. Mitchell L. Rev. 1375, 1379-82 (2012) (discussing that this standard emerged for children in light of the special protection that they need).

167. USA Gymnastics Whistleblower Policy, supra note 127, \[ 4, 5.

168. Id. II 5 .

169. Id. 
the USAG website, and within USAG's past board minutes did not reveal any information as to the existence of such a role. ${ }^{170}$

The second problematic aspect of the way in which whistleblower reports are handled in this policy is that USAG's board of directors is completely absent from the process. An ideal whistleblowing policy requires mandatory reporting up the ladder to the board of directors who each have fiduciary duties to respond to red flags and other related concerns to which they are alerted. ${ }^{171}$ As the highest governing body of an organization and distinguishable from the officers who operate the entity on a daily basis, the board of directors is usually less prone to bias, and a direct report to it helps to assure that executives do not filter or block negative information from reaching their ears. ${ }^{172}$

In addition to the structural reforms discussed above, recent federal legislative developments should help prevent another abuse scandal in the gymnastics world, as well as in other organized sports. On February 14, 2018, the Protecting Young Victims from Sexual Abuse and Safe Sport Authorization Act of 2017 was signed into law. ${ }^{173}$ Aimed at preventing any future occurrence of sexual abuse of athletes, this law mandates that adults who interact with athletes in national governing bodies (like USAG) or amateur sports organizations "who learn[] of facts that give reason to suspect that a child has suffered an incident of child abuse, including sexual abuse" report this information to law enforcement or a childwelfare agency designated by the Justice Department as soon as possible, with

170. See Board of Directors Minutes, USA GyMnASTICs (2017), https://usagym.org/pages/aboutus/pages/boardminutes.html (last visited July 16, 2018).

171. See, e.g., 17 C.F.R. $\$ \S 205.1,205.3$ (2019) (as an example, the SarbanesOxley Act requires attorneys to report up the ladder to the board of directors any possible violations of the law as the best-placed entity to manage and address such concerns); Michael W. Peregrine \& Russell Hayman, Internal Investigations: The Role of the Nonprofit Board, Annual Meeting In-House Counsel Prog., Amer. Health Lawyers Asscn. (2007) (discussing how directors have "core fiduciary obligation[s] to respond to and investigate red flags" within the entity); Rikard Lundberg, Managing Risks Associated with the Securities and Exchange Commission's Whistleblower Bounty Program, AsPATORE, 2013 WL 936256, at *11 (2013) (noting that the board of directors should receive communications about whistleblower tips); see also In re Caremark Int'l Inc. Derivative Litig., 698 A.2d 959, 971 (Del. Ch. 1996) (holding that a board of directors' fiduciary duties include a duty of reasonable oversight).

172. See, e.g., Richard E. Moberly, Sarbanes-Oxley's Structural Model to Encourage Corporate Whistleblowers, 2006 BYU L. REV. 1107, 1121, 1138 (2006) (discussing the structural model of whistleblowing in which channels are available to report information to the board of directors and the benefits of such a model); Jennifer M. Pacella, Bounties for Bad Behavior: Rewarding Culpable Whistleblowers Under the Dodd-Frank Act and Internal Revenue Code, 17 U. PA. J. Bus. L. 345, 347-48 (2015) (noting that the free flow of information to the board of directors assists with avoiding financial and other scandals within entities).

173. Protecting Young Victims from Sexual Abuse and Safe Sport Authorization Act of 2017, Pub. L. No. 115-26, 132 Stat. 318 (2018). 
penalties imposed for failure to report. ${ }^{174}$ The law also extends the statute of limitations for victims to sue sex-crime perpetrators to allow those who are abused as minors a chance to seek redress, as many may not realize that they have been abused until adulthood. ${ }^{175}$ In addition, the law authorizes the U.S. Center for Safe Sport, an organization launched by the U.S. Olympic Committee after the Nassar scandal, to investigate and resolve allegations of abuse associated with the national governing bodies (like USAG); to monitor all national governing bodies for compliance with the reporting requirements; and to take measures to ensure that athletes can report alleged abuse to an independent entity that will investigate and resolve the issues. ${ }^{176}$ Other measures incumbent upon the U.S. Center for Safe Sport pursuant to this law include the development of educational resources to promote reporting, procedures to prohibit retaliation by national governing bodies against reporters, and, importantly, the development of procedures to limit one-on-one interactions between a minor athlete and an adult at facilities under the jurisdiction of national governing bodies. ${ }^{177}$ It is the Authors' hope that the combination of these legal developments and the structural reforms proposed herein would ensure that another sexual perpetrator could never endure, let alone exist, within organized sports.

\section{B. Unionization}

Unionization, meanwhile, presents an additional means to provide legal protections to U.S. women's gymnasts - facilitating their empowerment, autonomy, and potential for shared governance over the operation of USAG. Congress passed the National Labor Relations Act ("NLRA") in May of 1935 to grant private employees the right to self-organize and "engage in concerted activities for the purpose of collective bargaining or other mutual aid or protection." 178 The NLRA "arose out of the necessities of a labor situation where a single employee was helpless in dealing with an employer based on fundamental differences in size and

174. Id. $\S 101(\mathrm{a})(2)$ (such persons required to report under the statute are referred to as "covered individuals."); see also Press Release, Sen. Dianne Feinstein, Senate Passes Bill Requiring U.S. Amateur Athletic Organizations to Report Sexual Abuse, FEInsteIN SENATE (Nov. 14, 2017), https://www.feinstein.senate.gov/public/index.cfm/press-releases? $\mathrm{ID}=2 \mathrm{BEC} 8 \mathrm{C} 16-43 \mathrm{E} 4-412 \mathrm{~A}-8660-3 \mathrm{E} 7 \mathrm{EC} 73104 \mathrm{~F} 9$.

175. See Protecting Young Victims from Sexual Abuse and Safe Sport Authorization Act of 2017, § 102(2).

176. See id. tit. 2.

177. See id. § 220530; see Feinstein, supra note 174; see also Senate Hearing, supra note 45, at 00:26:26, 01:04:39 (statement of Rick Adams, U.S. Olympic Committee, National Governing Body Organizational Development Chief) (discussing the latest efforts of the U.S. Center for Safe Sport to prevent any further instance of abuse against athletes).

178. National Labor Relations Act $\$ 7$ (1935) (codified as amended at 29 U.S.C. $\S$ 157 (2019)). See generally Michael H. LeRoy, Courts and the Future of 'Athletic Labor' in College Sports, 57 ARIZ. L. REV. 475, 504 (2015) (explaining that the National Labor Relations Act "applies only to private-sector employment."); Steven Willborn, College Athletes as Employees: An Overflowing Quiver, 69 U. Miami L. Rev. 65, 69 (2015) (describing the National Labor Relations Act as "a preemptive federal law governing collective employee rights in the private sector."). 
bargaining power between the parties." 179 Much like other workers who have unionized under the NLRA, individual U.S. women's gymnasts are "helpless" without union protection because USAG has monopoly power to control who may compete in Olympic gymnastics on behalf of the United States. ${ }^{180}$ Thus, absent a women's gymnasts union, even a single conflict between a potential Olympic gymnast and USAG could derail the ability to compete on the highest level and earn both prize money and endorsement dollars. ${ }^{181}$

\section{Unionizing Goals and Legal Standards}

The primary goal of the NLRA is to reduce this power differential between employers and labor by allowing members of a labor force to bargain in groups, rather than as individuals. ${ }^{182}$ More specifically, the Act instills a legal obligation on employers to bargain collectively with an established labor union over the mandatory terms and conditions of employment-hours, wages, and other working conditions. ${ }^{183}$ In other words, the Act does far more than simply allow workers to collect higher salaries. It also allows them to have more control over their workplace lifestyle in general.

Pursuant to the NLRA, the National Labor Relations Board ("NLRB") may choose to assert jurisdiction over any group of private, non-managerial workers and recognize them as a union if, among other requirements, the workers meet the statutory definition of "employees." 184 Although the NLRA does not explicitly define who is an "employee," the common-law definition for an "employee" includes any person who "performs services for another under a contract of hire,

179. Marc Edelman, The Future of College Athlete Players Unions: Lessons Learned from Northwestern University and Potential Next Steps in the College Athletes, Rights Movement, 38 CARDOZO L. REV. 1627, 1629 (2017) (quoting NLRB v. Jones \& Loughlin Steel Corp., 301 U.S. 1, 33 (1937) (internal citations and quotations omitted).

180. See Patty, supra note 12 (explaining how the Amateur Sports Act of 1978 gave the USAG exclusive control over determining which U.S. women's gymnasts would compete in the Olympics). See generally United States v. I.E. DuPont de Nemours \& Co., 351 U.S. 377, 391 (1956) (defining "monopoly power" as "the power to control prices or exclude competition"); United States v. Aluminum Co. of America, 148 F.2d 416, 424 (2d Cir. 1945) (explaining that control of $90 \%$ of a relevant market is enough to constitute monopoly power, although "it is doubtful whether sixty or sixty-four percent would be enough").

181. See generally I.E. DuPont de Nemours \& Co., 351 U.S. at 391 (recognizing that, along with "market power," comes the economic ability to "exclude competition"). See also Victor Mather et al., It's Official: Simone Biles Is the World's Best Gymnast, N.Y. TimES (Aug. 11, 2016), https://www.nytimes.com/2016/08/12/sports/olympics/simone-bileswomens-gymnastics-all-around-gold.html (explaining that a gymnast's victory in the Olympic Games "brings lucrative endorsements and widespread adoration, a popularity bonanza fueled by a prime-time showcase of athletic artistry").

182. Edelman, supra note 179, at 1629.

183. See First Nat.1 Maint. Corp. v. N.L.R.B., 452 U.S. 666, 674-75 (1981) (citing 29 U.S.C. § 158(d)) (“Although parties are free to bargain about any legal subject, Congress has limited the mandate or duty to bargain to matters of 'wages, hours, and other terms and conditions of employment."').

184. See, e.g., Trs. of Columbia Univ. N.Y.C., 364 NLRB Dec. (CCH) No. 90, 2 (2016). 
subject to the other's control or right of control, and in return for payment." ${ }^{185}$ While the NLRB is not required to adopt this definition, it often considers this definition to serve as the appropriate starting point to its analysis.

Breaking down each of these four components to the common-law definition of "employee," a person who "performs a service" is one who engages in an activity in which a reasonable person, absent any coercion, would generally expect compensation. ${ }^{186}$ By contrast, somebody who performs an act "solely for his personal purpose or pleasure," absent any coercion, would generally not be deemed an employee. ${ }^{187}$ To illustrate this point, in Walling v. Portland Terminal Co., the U.S. Supreme Court held that individuals who were enrolled in a seven- or eightday training course to become railroad-yard brakemen did not constitute employees, even though they performed a small amount of work under direct supervision, because these individuals were "in much the same position as students in a school," and thus they were not reasonably under the expectation of payment for the limited amount of work they completed. ${ }^{188}$ Meanwhile, in a subsequent case, the U.S. Supreme Court explained that even if the individuals in Walling had considered themselves to be "volunteers," they still might reasonably constitute "employees," in the legal sense, if these individuals had engaged in these activities for a longer period of time and thus reasonably could have expected payment in exchange for them. ${ }^{189}$

Similarly, a "contract for hire" generally entails the payment of wages for work. ${ }^{190}$ However, the mere absence of an express or implied-in-fact contract related to compensation for work is not always determinative to the legal analysis performed by either a court or the NLRB. ${ }^{191}$ For example, either a court or the NLRB

185. Brown Univ., 342 NLRB Dec. (CCH) 483, 500, n. 27 (2004) (citing NLRB v. Town \& Country Elec. Inc., 516 U.S. 85, 94 (1995)).

186. See Tony \& Susan Alamo Found. v. Sec'y of Labor, 471 U.S. 290, 302-03 (1985).

187. Walling v. Portland Terminal Co., 330 U.S. 148, 152 (1947); cf. Tony \& Susan Alamo Found., 471 U.S. at 303 (explaining that "ordinary volunteerism" does not constitute the performance of a service for purposes of determining employment status).

188. Tony \& Susan Alamo Found., 471 U.S. at 299-300 (citing Walling, 330 U.S. at 153$)$.

189. See id. at 301 (citing Walling, 330 U.S. at 148).

190. See Contract for Hire, Unempl. Ins. Rep. P 7506934 (CCH), 2015 WL 7506934, If 1332.20 (explaining that a "contract for hire" generally entails performing services for pay, but that the definition may encompass other situations as well, such as performing services in exchange for a share of company profits).

191. See generally Kevin DeMaio, Comment, Letting Go: NCAA Reform as an Alternative to the Unionization of College Athletes, 46 SETON HALL L. REV. 307, 322 (2015) (noting that some courts have held that an express or implied-in-fact "contract for hire is not always necessarily included in the common law definition of an employee" and that rather, "the appropriate common law definition of employee states: 'A worker is an employee when she "performs services for another, under the other's control or right of control, and in return for payment."'”). Cf. Stepp v. Freeman, 694 N.E.2d 510, 514 (Ohio Ct. App. 1997) (defining an "express contract" as one where "assent to the terms of the contract is actually expressed in the form of an offer and an acceptance" and defining an "implied-in-fact contract" as one 
may find an "implied-in-law" employment agreement, even absent an actual agreement, to prevent a powerful employer from exploiting would-be workers. ${ }^{192}$ Along the same lines, a court or the NLRB may find a contract for one to provide his or her services to another to constitute a "contract for hire" even absent the promise by the purported employer to make a monetary payment as long as general principles of fairness and equity would support such as result. ${ }^{193}$

Along the same lines, operating pursuant to another's "right of control" involves the alleged employer limiting freedoms of purported workers in a significant manner. ${ }^{194}$ In the context of organized sports, Region 13 of the NLRB previously has held that Northwestern University exercised "control" over its grantin-aid college football players who engaged in 40 to 50 hours per week of footballrelated activities during their fall academic semester. ${ }^{195}$ Beyond these heavy time commitments, Northwestern University's football coaches also determined the players' attire when traveling to road games, controlled whether the players were allowed to seek outside employment, monitored all football-player communications with the media, and even decided what contents the football players were allowed to post on the Internet. ${ }^{196}$

Finally, the performance of work "in return for payment" generally entails the expectation of the payment of money by the purported employer to the purported

where "the parties' meeting of the minds is shown by the surrounding circumstances, including the conduct and declarations of the parties, that make it inferable that the contract exists as a matter of tacit understanding").

192. See generally Tony \& Susan Alamo Found., 471 U.S. at 306 (finding an employment relationship even where many of the workers purported to be volunteers based on principles of fundamental fairness); Rachel Dalton, Third and Goal: High School Athletic Association Restrictions and the Privileges and Immunity Clause, 44 J. L. \& EDUC. 631, 634 (2015) (explaining that Region 13 of the NLRB found the "offer letter" provided to Northwestern University's football players constituted a "contract for hire" even though it did not provide direct, monetary pay); Speedway Inc. v. Job Service N.D., 454 N.W.2d 526, 528 (N.D. 1990) (internal quotations omitted) (noting that "[s]ince the Legislature has defined wages as meaning 'all remuneration for service from whatever source...', the phrase 'contract of hire,' to be meaningful under the statute, must encompass services other than or in addition to those performed for wages, as defined by the statute."). Cf. Stepp, 694 N.E.2d at 513-14 (explaining that because an implied-in-law contract is not a true contract but rather a "tool of equity, the existence of an implied-in-law contract does not depend on whether the elements of a contract are proven").

193. See Dalton, supra note 192, at 634 (explaining that Region 13 of the National Labor Relations Board found the "offer letter" provided to Northwestern University's football players constituted a "contract for hire" even though it did not provide direct, monetary pay).

194. See Grace v. Magruder, 148 F.2d 679, 681 (D.C. Cir. 1945) ("[t]he vital element which negatives such independence, in the relation between employer and employee, is the right to control the employee, not only as to the final result, but in the performance of the task itself," and that "it is the right to control, not control or supervision itself, which is most important.").

195. Northwestern Univ., No. 13-RC-121359, 2014 WL 1246914, at *13-15 (N.L.R.B. Mar. 26, 2014).

196. See Edelman, supra note 179, at 1638-39 (citing Northwestern Univ., 2014 WL 1246914 , at $* 16-17)$. 
employee. ${ }^{197}$ However, as elucidated by the U.S. Supreme Court in Tony \& Susan Alamo Foundation v. Department of Labor, such a "payment" does not, as a matter of law, need to be monetary in nature. ${ }^{198}$ In that case, the Court specifically held a private foundation had indeed made a payment to its staff of "volunteer" employees because the foundation had provided these employees, in exchange for their services, with "food, clothing, shelter, and other benefits."199 Similarly, in Northwestern University v. College Athletes Players Association, Region 13 of the NLRB held that the grant-in-aid recipient college football players at Northwestern University constituted employees and thus implicitly received "payment" from their college in the form of their academic scholarships, even though these athletes did not receive any monetary payment from their college. ${ }^{200}$

\section{Elite U.S. Women's Gymnasts as Employees}

Based on the above components to the common-law definition of "employee," one can make a strong argument that U.S. elite women's gymnasts meet the technical standard of "employees" under the National Labor Relations Act, even though either a court or the NLRB is within its right to define the term "employee" even more broadly. ${ }^{201}$

With respect to the first element of the common law test for employment, the U.S. women's gymnasts "perform a service" for which a reasonable person would indubitably have the expectation of payment. ${ }^{202}$ At present, the gymnasts' labor services are vital to USAG's ability to generate television revenues from gymnastics sporting events. Indeed, during the 2012 Summer Olympic Games in London, England, the televised broadcasts of the U.S. women's gymnastics team drew, on average, 38.7 million viewers - ratings that exceed all other "amateur" sporting events. ${ }^{203}$ The television ratings for gymnastics events in the 2012 Summer

197. Tony \& Susan Alamo Found., 471 U.S. at 306.

198. Id.

199. Id. at 298, 301 .

200. Northwestern Univ., 2014 WL 1246914, at *16-17; see also Edelman, supra note 179 , at 1638 (describing the college football players' "tender" as an "employment contract that guarantees football players compensation in the form of both a free education and living stipends").

201. See infra notes 202-17 and accompanying text; see also Rachelle Propson, Note, A Call for Statutory Regulation of Elite Child Athletes, 41 WAYNE L. REV. 1773, 1783 (1995) (explaining that even purported amateur athletes such as gymnasts training for the Olympic Games "often find their sports to be a vocation").

202. See generally Tony \& Susan Alamo Found., 471 U.S. at 302-03 (discussing "performance of a service" and reasonable expectation of pay).

203. Hoffman, supra note 70, at 579; Scott Collins, London Olympics: U.S. Gymnastics Gold Powers NBC to Big Ratings, L.A. Times (Aug. 1, 2012), http://articles.latimes.com/2012/aug/01/entertainment/la-et-st-olympics-2012-womensgymnastics-gold-powers-nbc-to-high-ratings-20120801. By way of comparison, these television ratings compare favorably to those of the most popular college sporting events, including even the NCAA Men's Basketball Tournament National Championship game and the college football Bowl Championship Series football championship game; see 2015 Tourney Most-Watched in 22 Years, NCAA (Apr. 7, 2015), https://www.ncaa.com/ news/ncaa/article/2015-04-07/2015-ncaa-tournament-has-highest-average-viewership-22- 
Olympic Games also outperformed most "professional" events, including even past deciding games of the National Basketball Association's championship series. ${ }^{204}$ These television revenues, in turn, are used to cover the high salaries and "exorbitant" lifestyles of those affiliated with the U.S. Olympic Committee, including administrators and overseers of USAG. ${ }^{205}$ At the heart of the general doctrine of intellectual property law, there lies a well-established principle that if you create something, then it is yours to exploit. ${ }^{206}$ Based upon this principle, one would logically expect that, if not for the monopoly power granted to USAG over U.S. gymnastics, women's gymnasts reasonably could have expected to receive pay, in addition to prize money, for their services. ${ }^{207}$

Turning next to the question of whether there is a "contract for hire" between the elite U.S. women's gymnasts and USAG, the answer here is probably yes. ${ }^{208}$ Unlike professional athletes who compete in organized team sports, U.S. competitive gymnasts earn their salaries through prize money that is paid to top performers based on their scores in national and international events, as well as through sponsorship agreements they secure with third-party brands. ${ }^{209}$ For an American gymnast to gain eligibility to compete for prize money (and, thus, to gain the needed attention for sponsorship opportunities), a gymnast must be part of a gymnastics club that is eligible for USAG membership, as well as personally apply

years (listing viewership for the 2015 NCAA Men's Basketball Championship game at 28.3 million).

204. Dominic Patten, NBA Finals Game 7 Most Watched Game Ever on ABC as Cavs Win First Title, DEADLINE (Jun. 20, 2016), http://deadline.com/2016/06/lebron-jamesnba-finals-ratings-game-7-cleveland-cavaliers-golden-state-warriors-abc-1201775472 (stating that Game 7 of the 2016 NBA Finals featuring LeBron James and Stephen Curry received 30.8 million views and the 106th Academy Awards received 34.4 million views).

205. Sally Jenkins, Congress Must Fix the USOC, and That Includes Exorbitant Executive Spending, THE WASHINGTON POST (Mar. 27, 2018), https://www.washingtonpost.com/sports/olympics/congress-must-fix-the-usoc-and-thatincludes-exorbitant-executive-spending/2018/03/26/a051c898-3128-11e8-94fa-

32d48460b955_story.html?noredirect=on\&utm_term=.9e34a $4 \mathrm{~d} 7215 \mathrm{~d}$ (referencing the “\$800,000 salaries" of U.S. Olympic Committee officials).

206. Marc Edelman, Closing the "Free Speech" Loophole: The Case for Protecting College Athletes' Publicity Rights in Commercial Video Games, 65 FL. L. REV. 553, 555 (2013).

207. See Tony \& Susan Alamo Found., 471 U.S. at 302-303; see also Jenkins, supra note 205 (explaining that according to the U.S. Olympic Committee's annual disclosure form, only about $80 \%$ of the association's revenues are paid out to the athletes); see also Propson, supra note 201, at 1808 (explaining that "the existence of an employment relationship is not controlled by the parties' technical relationship or the fact that the child receives no compensation").

208. See infra notes 209-11 and accompanying text

209. Malkia McLeod, The Average Salary of Gymnasts, CAREER TrEND (Jul. 5, 2017), https://careertrend.com/info-8642049-average-salary-gymnasts.html (discussing the payment of cash prizes and endorsements paid to high-ranking athletes involved with U.S. Gymnastics). 
and be granted membership to USAG. ${ }^{210}$ In conjunction with such membership, the gymnasts must further agree to a number of requirements to maintain their eligibility to compete for prizes, including granting USAG the right to profit off their likenesses, and participating in events that generate revenue with USAG, the U.S. Olympic Committee, and the Fédération Internationale de Gymnastique through the sale of game tickets, media rights, and sponsorship rights. ${ }^{211}$

With regard to the third element of a common-law employment relationship pertaining to "right of control," the time commitments placed by USAG on elite female gymnasts, along with the undeniable limiting of their freedoms, present a strong case in favor of finding the exercise of control by a purported employer. ${ }^{212}$ Indeed, this level of extreme and persistent control exercised by USAG over its elite female gymnasts appears, in part, based on the USAG requirement that its competitive gymnasts train "seven hours per day, six days a week" - a time commitment at least on par with that required from the Northwestern University grant-in-aid college football players who Region 13 found to be "employees." 213 In addition, the elite female gymnasts who compete for USAG are required to surrender most, if not all, choices about their nutrition, medical treatment, and access to doctors, as well as sometimes forgo seeing their parents and other family members for extended periods of time. ${ }^{214}$ While the mere provision of nutritional advice in itself would perhaps not rise to the level of control that would support the finding of an employment relationship, the methodical forcing of young gymnasts to physically "go to bed hungry" far exceeds the level of control that one would ever expect to see within an autonomous activity. ${ }^{215}$

Finally, regarding the common-law requirement that the performance of work occur "in return for payment," even despite USAG's drastic efforts to avoid direct pay to athletes, elite female gymnasts that compete for USAG still receive prize money and endorsement deals-compensation that one could reasonably consider cy pres to the direct salaries they would receive on a free market. ${ }^{216}$ Furthermore, based on the legal monopoly that USAG enjoys over selecting U.S. Olympic gymnasts under the Amateur Sports Act, it is able to secure the services of

210. Athlete Membership, USA GYMNASTICS, https://usagym.org/pages/ membership/pages/info_athlete.html (last visited June 8, 2019).

211. USA Gymnastics 2017 National Team Funding and Support Agreement, USA GYMnASTICS, https://usagym.org/PDFs/Pressbox/Selection\%20Procedures/17natteam _agreement.pdf (last visited June 8, 2019).

212. See infra notes $213-15$ and accompanying text.

213. Hamilton, supra note 77, at 44; see also Propson, supra note 201, at 1773, 1776 (describing the training regimen of Christy Henrich, a U.S. women's gymnast who died from multiple eating disorders, as "seven hours a day" and purporting that some young gymnasts and figure skaters actually train for up to eight hours per day); see also Northwestern Univ., No. 13-RC-121359, 2014 WL 1246914, at *16-17 (N.L.R.B. Mar. 26, 2014).

214. See supra notes 73-78 and accompanying text.

215. See Hoffman, supra note 70, at 572.

216. See Propson, supra note 201, at 1784-85 (discussing the pay of elite child athletes such as figure skaters and gymnasts in the form of endorsement contracts). 
elite gymnasts without paying them directly - knowing full well that any gymnast that refuses to accept the USAG's terms of employment will, in essence, forgo any alternative opportunity to secure payment in the form of prize money and endorsement deals - thus making the participation with USAG and the ability to secure these other forms of pay, in essence, part and parcel to one another. ${ }^{217}$

Based upon the foregoing, there is an overwhelmingly strong argument that elite women's gymnasts in the United States meet the common-law definition of "employee." Thus, at least pursuant to the common-law standard, they operate within the framework of an employment relationship with a private employer in USAG.

\section{Labor Board Discretion}

Nevertheless, under labor law, the NLRB retains the discretion to decline jurisdiction over any group of employees if it believes that asserting jurisdiction would not serve to promote stability in labor relations or would fundamentally interfere with broader national policy. ${ }^{218}$ Here, NLRB can technically decline jurisdiction for any reason or for no reason at all. However, in the context of a prospective union including elite USAG gymnasts, it is not very likely that the NLRB would decline jurisdiction on purely public policy grounds.

Historically, the common reason why the NLRB has applied its discretion to decline jurisdiction has been based on concerns over how asserting jurisdiction over American employees that are physically based in U.S. controlled territories abroad would affect the nation's foreign relations. ${ }^{219}$ In August 2015, the NLRB also somewhat surprisingly declined jurisdiction over Northwestern University's grantin-aid college football players. ${ }^{20}$ There, the Board's decision was based upon the fear that, if it were to assert jurisdiction, it would upset the on-field balance of power between Northwestern University's college football team and the college football

217. See generally Steven Sexton, The U.S. Olympic Monopoly Needs Accountability, WALL STREET J. (Mar. 29, 2018, 6:55 PM), https://www.wsj.com/articles/theu-s-olympic-monopoly-needs-accountability-1522364127 (explaining that the U.S. Olympic Committee "is a monopsonist employer of Olympic athletes" and "the only buyer of their talents").

218. NLRB v. Denver Bldg. Trades Council, 341 U.S. 675, 684 (1951) ("the Board sometimes properly declines to do so, stating that the policies of the Act would not be effectuated by its assertion of jurisdiction in that case"); see also Northwestern Univ., No. 13 RC-121359, 2015 WL 4882656, at *5 (N.L.R.B. Aug. 17, 2015) (concluding that the assertion of jurisdiction over a single team in a college football conference consisting of 14 teams would not "promote stability in labor relations" within that college football conference).

219. See, e.g., Contract Serv., Inc., 202 NLRB Dec. (CCH) 862, 864-65 (1973) (declining to assert jurisdiction over bus transportation employees operating within the United States controlled Panama Canal Zone because "the issue of Panamanian sovereignty over the Canal Zone has long been a sensitive topic of negotiations" and the NLRB did not want to grant jurisdiction over the exclusively Panamanian employees of a Delaware bus company that transported U.S. military workers in fear of overreaching in the mind of the Panamanian government).

220. Northwestern Univ., 2015 WL 4882656, at *5. 
teams of the other thirteen state public colleges that play football in the Big Ten Conference. 221

In the context of recognizing a potential union consisting of elite female gymnasts, asserting jurisdiction would not hamper stability in labor relations, nor would asserting jurisdiction fundamentally interfere with any broader national policy. ${ }^{222}$ Indeed, as first reported by Sally Jenkins of the Washington Post, the current labor relations in U.S. Olympic sports are already in rather bad shape, with officials affiliated with the U.S. Olympic Committee "feeding on filet mignon while ignoring athletes who are abused and on food stamps." 223 Moreover, even though USAG gymnasts compete in certain international events against gymnasts who are not unionized, the asserting of jurisdiction over U.S. competitive gymnasts would not place an undue burden on any foreign entity or government as all of the competitors involved with U.S. gymnastics are American citizens who perform all of their training and some of their competitions on American soil. ${ }^{224}$

Even the concerns related to on-field competitive balance that emerged in the Northwestern University unionization case would not apply with respect to U.S. women's gymnasts - at least not to nearly the same magnitude. In national gymnastics events, such as the Nastia Liukin Cup, American Cup, U.S. Classic, and USA Gymnastics Championships, all of the competitors would be members of USAG-thus, all competitors would have the opportunity to join the same union. ${ }^{225}$ This is fundamentally different from the case where the football players from Northwestern University sought to unionize, but doing so would have left the players from the other 13 colleges within their same conference without a union. ${ }^{226}$

Lastly, there are strong public policy reasons in the case of the U.S. women's gymnasts that would favor allowing them to unionize-extending far beyond the technical employer-employee nature of the underlying relationship. ${ }^{227}$ Numerous scholars have suggested that it is more important for the NLRB to assert jurisdiction over workers in the context of ongoing "mischief" to protect the weaker

221. See Edelman, supra note 179, at 1639-40 (citing Northwestern Univ., 2015 WL 4882656, at *5).

222. See Denver Bldg. Trades Council, 341 U.S. at 684 (stating that "the Board sometimes properly declines to do so, stating that the policies of the Act would not be effectuated by its assertion of jurisdiction in that case"); see also Northwestern Univ., 2015 WL 4882656 , at $* 5$ (concluding that the assertion of jurisdiction over a single team in a college football conference consisting of fourteen teams would not "promote stability in labor relations" within that college football conference).

223. Jenkins, supra note 205.

224. This differentiates the facts here with those in cases such as Contract Serv., Inc., 202 NLRB Dec. (CCH) at 864-65, where the NLRB declined to assert jurisdiction over employees operating within the United States controlled Panama Canal Zone because "the issue of Panamanian sovereignty over the Canal Zone has long been a sensitive topic of negotiations."

225. 2019 Premier Events, USA GYMNASTICS, https://usagym.org/pages/events/ pages/premier_events.html (last visited June 29, 2018).

226. See Edelman, supra note 179, at 1640.

227. See infra notes 228-29 and accompanying text. 
party from continuing the sustained abuses without a meaningful voice. ${ }^{228}$ The monstrous sexual abuse that USAG's gymnasts experienced for such a sustained duration is one of the many instances in which "mischief" is undeniable - in part enabled by their systematic disempowerment. Indeed, it would be naive to think that the coaches of USAG are adequately positioned to fully advocate for the best interests or well-being of the U.S. women's gymnasts. Indeed, the coaches' interests are often misaligned with those of the gymnasts given that "[c]oaching is a profession, and as such, coaches depend upon the success of their child athletes" to propagate their own careers - and not the child athlete's long-term well-being. ${ }^{229}$

Given that under the current system there is not necessarily any individual looking out for the true interests of the USAG gymnasts, the establishment of an NLRB-recognized union with a legal duty to protects the gymnasts' best interests serves as an important step toward keeping these young, female gymnasts physically and emotionally safe.

\section{CONCLUSION}

The abuse of hundreds of female gymnasts while in pursuit of their athletic dreams has brought to light not only the sad reality that a sexual perpetrator endured for nearly 20 years without discovery, but also that USAG failed to ensure the safety of the very individuals it promised to protect. Since the 1980s, USAG and its coaches have established a strict culture of harsh and intimidating training conditions and belittlement to ensure their gymnasts reach Olympic levels and gain international fame and recognition. ${ }^{230}$ The facilitation of a culture of silence within USAG led to circumstances making it possible for Nassar to prey on his victims, earn their trust and that of the larger gymnastics and medical community, and to commit countless instances of sexual abuse and molestation against the hundreds of young females who sought the help of their doctor when in pain and injured. ${ }^{231}$

This type of culture, combined with the lack of any existing or operational internal or external reporting channels, prevented the knowledge of abuse from ever reaching anyone who was in a position to stop it from continuing to occur-rather, Nassar abused girls and women for nearly two decades, leading to hundreds of victims who came forward to give their statements at his sentencing hearings in 2018. ${ }^{232}$ Nassar is now serving a lifetime prison sentence and can no longer pose harm to young females, but unfortunately, the flawed system of detecting and properly addressing allegations of sexual abuse, or any wrongdoing for that matter, persists, and USAG is in need of complete overhaul to revamp its culture and to ensure the protection of its athletes. ${ }^{233}$

228. Propson, supra note 201, at 1808 (quoting Allen L. Schwartz, Annotation, Validity, Construction, Application and Effect of Child Labor Provisions of Fair Labor Standards Act, 21 A.L.R. Fed. 391, 418 (1993)).

229. Id. at 1787.

230. See supra Parts I.A, II.

231. See supra Part II.

232. See supra Part II.

233. See supra Sections II.B., II.C., III.A. 
These unfortunate events can be avoided in the future through the legal and structural reforms that the Authors have proposed herein. This Article calls for two main reforms that would be conducive to ensuring that another similar scandal could never occur: the creation of an effective whistleblower protection system and the unionization of female gymnasts. While USAG does have a brief whistleblowing policy on the books, it is ineffective in many ways due to its lack of inclusion of the gymnasts themselves as eligible for retaliation protections, the lack of involvement of USAG's board of directors in receiving and addressing whistleblower reports, and the absence of mention of external reporting as a protected activity. ${ }^{234}$

This Article proposes reforms to USAG's whistleblower policy while highlighting the importance of a reporting obligation for all constituents of USAG, including the gymnasts themselves with protection from retaliation based on the most lenient standard, the subjective standard, which would offer protections to whistleblower-gymnasts in all cases except knowingly making a false report. ${ }^{235}$ The development of this type of whistleblowing program, which contains provisions that are optimal for both protecting and incentivizing whistleblowers to come forward, must be combined with an overhaul of USAG's culture, which has for too long repressed gymnasts and created a "groupthink" environment in which red flags were never questioned, let alone raised. ${ }^{236}$ The creation of a culture that welcomes the free flow of information and advertises and educates gymnasts, parents, and coaches about appropriate training techniques and inappropriate behaviors or interactions between those in positions of superiority over gymnasts would serve to improve the environment of USAG, making it more conducive to ensuring that the safety of its athletes is the ultimate goal.

At the same time, the unionizing of U.S. Olympic gymnasts would afford these gymnasts access to "bona fide representation separate and apart from the private and commercial entity known as USA Gymnastics." 237 This is important because the monetary interests of USAG are often unaligned with the well-being of the gymnasts themselves. Sadly, under the status quo, there is a strong financial interest for the administrators associated with USAG to promote winning at all costs. This mentality has let USAG turn a blind eye to their coaches' emotionally abusive treatment of female gymnasts, and even the widespread and persistent sexual abuse of more than 250 gymnasts by the team's longstanding doctor, Larry Nassar.

The Authors hope that, with the implementation of the legal and structural reforms proposed herein, future generations of gymnasts will have only one concern in mind going forward - the pursuit of their Olympic dreams. By facilitating the adoption of a safe and healthy environment for young elite athletes, the official national governing bodies will have little alternative but to reform their sports in a manner consistent with true American ideals. As a result, the process of preparing

234. See supra Section III.A.

235. See supra Section III.A.

236. See supra Section III.A.

237. Marc Edelman, Why Unionizing is a Reasonable Option for the U.S. Women's Gymnastics Team, Forbes (Jan. 22, 2018, 10:15 AM), https://www.forbes.com/sites/ marcedelman/2018/01/22/why-unionizing-is-a-reasonable-option-for-the-u-s-womensnational-gymnastics-team/\#700761162422. 
young athletes to compete in the Olympics could once again be one that provides great pride for our nation, and not a reason to express trepidation. 
Copyright of Arizona Law Review is the property of Arizona Law Review and its content may not be copied or emailed to multiple sites or posted to a listserv without the copyright holder's express written permission. However, users may print, download, or email articles for individual use. 